\title{
Inconsistencies and Controversies Surrounding the Amyloid Hypothesis of Alzheimer's Disease
}

\author{
Gary P Morris ${ }^{1,2}$, lan A Clark ${ }^{3}$ and Bryce Vissel ${ }^{1,2^{*}}$
}

\begin{abstract}
The amyloid hypothesis has driven drug development strategies for Alzheimer's disease for over 20 years. We review why accumulation of amyloid-beta $(A \beta)$ oligomers is generally considered causal for synaptic loss and neurodegeneration in AD. We elaborate on and update arguments for and against the amyloid hypothesis with new data and interpretations, and consider why the amyloid hypothesis may be failing therapeutically. We note several unresolved issues in the field including the presence of $A \beta$ deposition in cognitively normal individuals, the weak correlation between plaque load and cognition, questions regarding the biochemical nature, presence and role of A $\beta$ oligomeric assemblies in vivo, the bias of pre-clinical AD models toward the amyloid hypothesis and the poorly explained pathological heterogeneity and comorbidities associated with AD. We also illustrate how extensive data cited in support of the amyloid hypothesis, including genetic links to disease, can be interpreted independently of a role for $A \beta$ in $A D$. We conclude it is essential to expand our view of pathogenesis beyond $A \beta$ and tau pathology and suggest several future directions for AD research, which we argue will be critical to understanding AD pathogenesis.
\end{abstract}

Keywords: Alzheimer's disease, Amyloid hypothesis, Amyloid beta, Neurofibrilliary tangles, Tau, Synapse, Microglia, Astrocytes, Neuroinflammation, TNF, Neurodegeneration, Amyloid precursor protein, Plaque

\section{Introduction}

"Whenever a theory appears to you as the only possible one, take this as a sign that you have neither understood the theory nor the problem which it was intended to solve."

\section{- Karl Popper}

A hypothesis that remains unproven yet catches the collective imagination can become, with the passage of time, so seductive that it dominates peer review opinion and arrests the development of alternative ideas. Such is the case for the amyloid hypothesis of AD. From the mid-1980s [1,2] this hypothesis began to give focus and excitement to what had been an unstructured research

\footnotetext{
* Correspondence: brycevissel@gmail.com

'Garvan Institute of Medical Research, Neuroscience Department,

Neurodegenerative Disorders Laboratory, 384 Victoria Street, Darlinghurst, NSW 2010, Australia

${ }^{2}$ Faculty of Medicine, University of New South Wales, Sydney, Australia Full list of author information is available at the end of the article
}

field with dozens of complex and unrelated theories [3], none of which dominated. It became a simple and effective way to describe $\mathrm{AD}$ pathogenesis to funding bodies, pharmacological companies, and the public at large.

The hypothesis arose through the input of researchers with a history of observing prion particles $[4,5]$ seeing parallels between these entities in brain sections in CreutzfeldJacob disease and the plaques in $\mathrm{AD}$ brain, described years earlier [6]. It warrants recalling that a commentary [7] notes Alzheimer devoting only two sentences of his 1907 text to these plaques, and there being no reason to suppose that he or indeed anyone until the early 1980s, saw them as causal.

When Prusiner and Master's interest in these plaques began, others showed they consisted of a novel amyloid fibril $[1,8]$ containing highly aggregating small polypeptides about 40 amino acids long with a molecular mass of $4 \mathrm{kDa}$, now known as amyloid-beta $(\mathrm{A} \beta)$ [9]. The dense fibre-like tangles Alzheimer noted, now termed neurofibrilliary tangles (NFTs), contain bundles of paired helical filaments of the microtubule associated protein tau [10]. The 1980s ended with a report that the $A \beta$ peptide derived 
from the amyloid precursor protein (APP) was neurotoxic [11], transforming a histological parallel into the amyloid theory of disease pathogenesis.

Hence the basis of $\mathrm{AD}$ became, in essence, $\mathrm{A} \beta$ killing neurons, and later also $A \beta$ killing synapses, despite the syndrome clearly being more subtle and complex and the fact that histopathology lesions have a poor record of being causal in disease pathogenesis. Although the amyloid hypothesis has shifted its focus from plaque to soluble forms of $A \beta$, it largely remains defined by the central tenet that accumulation of amyloid, in a variety of forms, triggers a cascade that harms neurons and synapses (Figure 1).

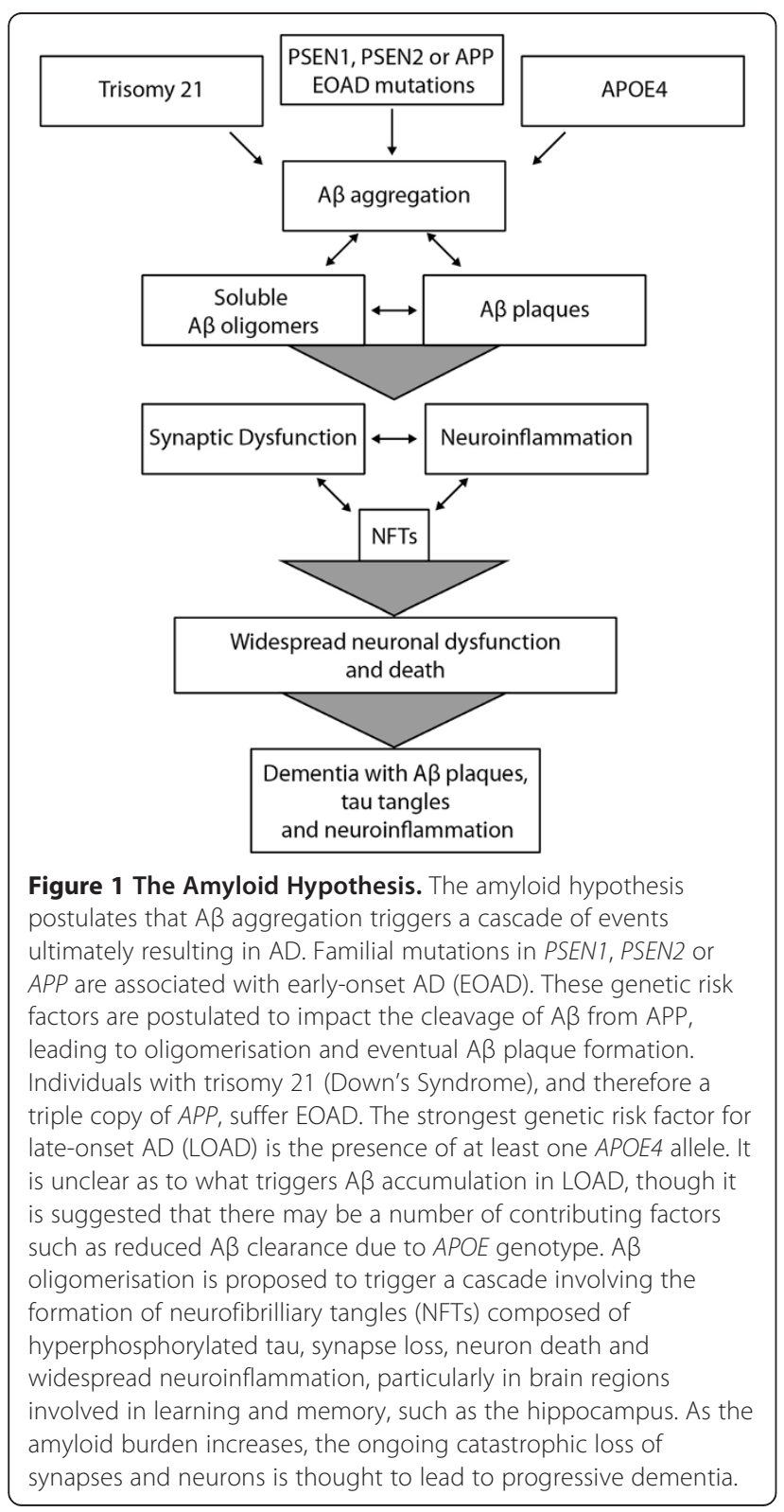

The amyloid hypothesis has become difficult to challenge because it is so often the lens through which peer reviewers, granting bodies and pharmaceutical companies view, judge and support AD research. Thus new non-amyloid data tends to be couched in terms that place it within the amyloid hypothesis and many authors tacitly ignore valid, but quite different, interpretations.

We show here however that the central conclusion of the amyloid hypothesis, that $\mathrm{A} \beta$ is the cause of $\mathrm{AD}$ is, at very least, premature. $A \beta$ is one product of amyloid precursor protein (APP) processing. Current data does support a conclusion that aberrant expression and processing of APP may sometimes cause human familial AD (FAD), also called early-onset AD (EOAD), and that $A \beta$, in excess, can be toxic. However, data does not support a conclusion that aberrant $A \beta$ expression is the cause of sporadic $\mathrm{AD}$, also known as late-onset AD (LOAD). In fact as we show data suggests that aberrant $A \beta$ expression may not be the primary cause of all EOAD. Instead, it may more often play a role, perhaps secondary, as part of more complex processes in the CNS. We suggest the field has matured sufficiently, with a range of alternative interpretations available, that a strong prospect for a change in direction exists that could provide a major advance in disease understanding and clinical interventions.

\section{The Amyloid Hypothesis}

The amyloid hypothesis postulates that amyloid-beta $(A \beta)$, in a variety of forms, triggers a cascade harming synapses and ultimately neurons, producing the pathological presentations of $\mathrm{A} \beta$ plaques, tau tangles, synapse loss and neurodegeneration, leading to dementia. $A \beta$ accumulation is thought to initiate AD pathology by destroying synapses, causing formation of NFTs, and subsequently inducing neuron loss (Figure 1). Although some changes to the hypothesis have occurred since the original publications, notably a shift toward defining soluble $A \beta$ oligomers as the toxic agent, rather than plaques, the theory and the way data is interpreted have remained largely the same, i.e. A $\beta$ accumulation as oligomers or plaques triggers AD. A large, growing literature espouses the amyloid hypothesis. In this section we summarise these data and how the dominance of this hypothesis arose.

\section{Putative evidence in support of the hypothesis}

Using the amino acid sequence corresponding to $A \beta$ [9], the major constituent of amyloid plaques in $\mathrm{AD}$, a precursor gene cDNA to $\mathrm{A} \beta$ (the amyloid precursor protein, APP) was sequenced and mapped to chromosome 21 [12]. This finding had compelling implications in view of the observation many individuals with trisomy 21 (Down's Syndrome) 
reach the neuropathogical criteria for $\mathrm{AD}$ by age 40 [13]. Such Down's individuals would have a triple copy of APP, and therefore it was reasoned, excess $A \beta$ production. Since $\mathrm{A} \beta$ is the main component of plaques seen in $\mathrm{AD}$, it is presumed in turn that excess $A \beta$ is the cause of AD in Down's syndrome. Surprisingly, the fact that not all people with Down's syndrome develop $\mathrm{AD}$, despite plaques and increased $A \beta$ expression, did not receive significant attention [13]. This observation may have quelled consideration of $\mathrm{A} \beta$ as the sole risk factor for $\mathrm{AD}$.

Next, studies of familial EOAD uncovered genetic links between the APP gene and AD [14]. APP is processed into smaller peptide fragments, one of which is
$\mathrm{A} \beta$, via cleavage by $\alpha-, \beta$ - and $\gamma$-secretases (Figure 2). Importantly, EOAD-linked point mutations were identified not only in APP itself but also in presenilin-1 (PSEN1) and presenilin-2 (PSEN2) $[15,16]$ the key catalytic subunits of $\gamma$-secretase, known to cleave APP (Figure 2). No known $\mathrm{AD}$-causing mutations are present in the gene encoding the $\beta$-secretase gene, beta-site APP cleaving enzyme 1 (BACE1).

The genetic mutations are reasoned to cause AD through aberrant processing of APP, leading to either increased levels of $A \beta$ or an increased production of the 42 and 43 amino acid forms of $A \beta(A \beta 42 / A \beta 43)$ over the 40 amino acid form of $A \beta$ (A $\beta 40)$. It is argued this triggers

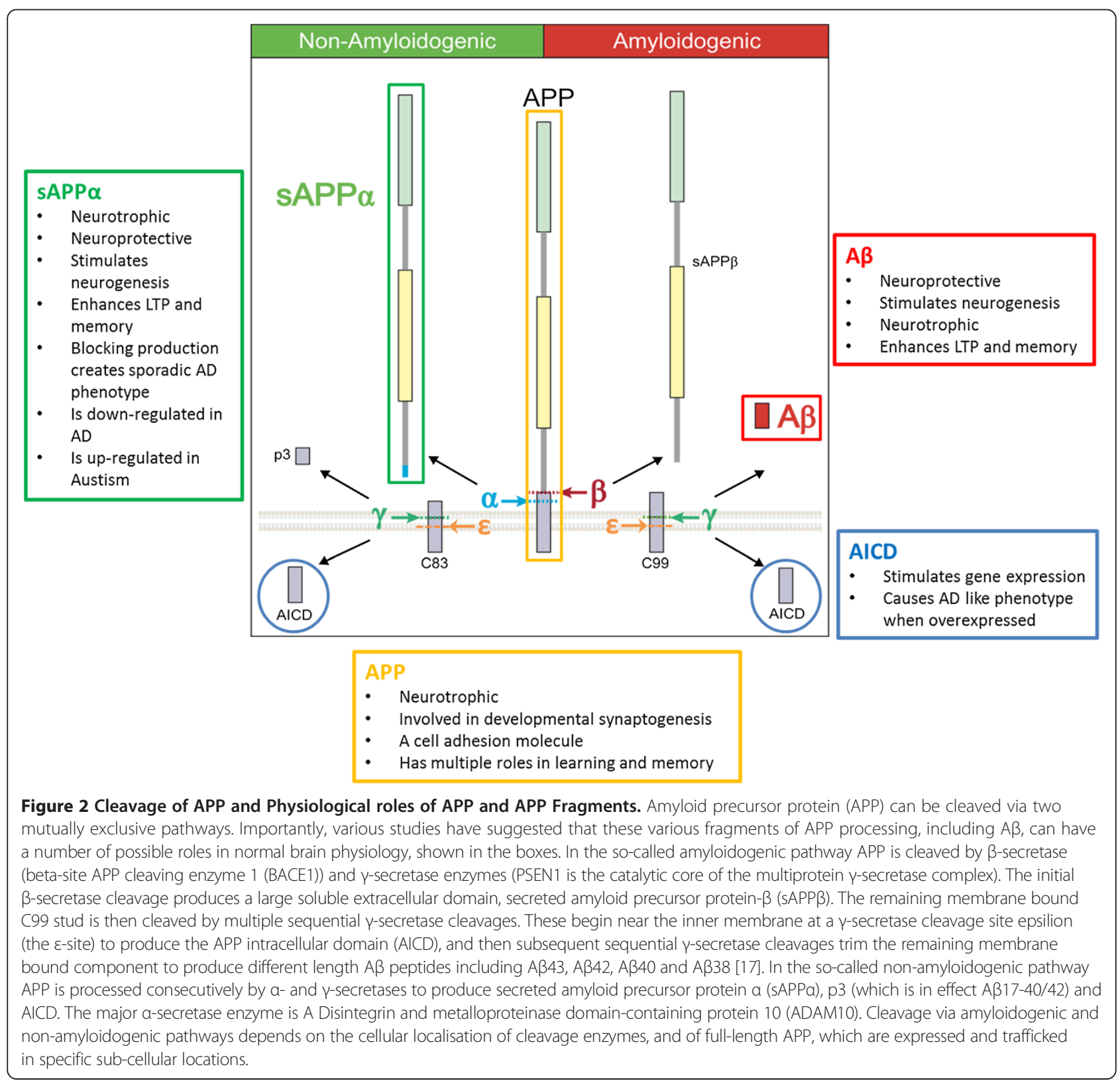


aggregation of $\mathrm{A} \beta$ [17]. The discovery that transgenic mice expressing familial human APP and PSEN mutations recapitulate many, but not all, of the features of the human disease [18] further established the link between aberrant $\mathrm{A} \beta$ production and the $\mathrm{AD}$ phenotype. This latter discovery, perhaps more than any other, tied the field to the amyloid hypothesis for the next decades.

The conclusions of the aforementioned studies were grounded in an unquestioned assumption that $A \beta$, rather than altered expression of APP or its products, causes AD pathology. The assumption arose because $A \beta$ was the key component of plaques and because $A \beta$ caused neurotoxicity in healthy cells [19]. Further, hyperphosphorylation of tau, thought to be downstream of $A \beta$, was seen as a critical mediator of the neurotoxic effects of $A \beta$ [20] placing $\mathrm{A} \beta$ at the top of the pathological chain of AD events. A cycle thus began to develop early whereby studies were designed and then interpreted on the basis of the hypothesis that $A \beta$ caused $A D$ pathology, rather than being critically evaluated in the context of a range of possible interpretations.

Further, given the impact discoveries of mutations in APP, PSEN1 and PSEN2 have had in driving the amyloid theory, it is notable that, while these mutations account for the majority of EOAD cases, EOAD only comprises less than $5 \%$ of all AD cases [21]. In fact, the majority of AD cases are sporadic, idiopathic LOAD. It seems in retrospect presumptive to have extrapolated a role for $\mathrm{A} \beta$ in all $\mathrm{AD}$ based on the genetic evidence suggesting a role for altered APP processing in EOAD.

In general, the risk genes identified for LOAD are subtle, with no direct genetic association to the APP gene or its processing enzymes. The most well-known genetic link to LOAD is the apolipoprotein genotype E4 (APOE4) [22]. Recently another strong risk gene for LOAD was identified, a variant of the triggering receptor expressed on myeloid cells 2 gene (TREM2), implicating excessive innate immunity in Alzheimer's pathogenesis [23]. Although these two mutations have been the strongest to date, many more have been associated with LOAD. Most of these genetic risk factors have been interpreted through the lens of the amyloid hypothesis, mainly by considering their modulatory effects on $A \beta$, though other interpretations are equally valid, an issue we discuss further in later sections.

\section{The crucial role of synapse loss in AD}

Synapse loss leads to a loss of dendritic mass [24] and, crucially, may precede, and indeed drive, neuron loss in a range of conditions [25]. Deficits in synaptic plasticity are measurable at just one month of age in mouse models of AD [26] and synapse loss is evident during early stages of the human disease [27]. Elegant research has revealed the number of neocortical synapses to be a better correlate of cognition than both $A \beta$ plaques and NFTs [28] and a greater loss of synapses than neurons is evident in human AD brains [29]. These observations place synapses at the forefront of understanding $A D$ pathogenesis. It has therefore been suggested that AD is primarily a synaptic disorder [30,31]. In a mouse model of $\mathrm{AD}$, synapse loss arises from over-elimination of synapses, rather than a failure of synapse formation [32].

\section{Putative evidence that $A \beta$ causes synapse dysfunction and loss in vitro and ex vivo}

The obvious caveat of in vitro studies is that they may not represent actual processes in the brain. Nevertheless, much work focuses on the impact of $A \beta$ oligomers on synapses, most of it in in vitro or ex vivo culture systems.

Key in vitro findings are summarised as follows; $A \beta$ oligomers bind exclusively and rapidly to synaptic terminals [33], altering both pre- and postsynaptic structures in cultured neurons and affecting excitatory, but not inhibitory nerve terminals [34]. The effects of $A \beta$ on synapse formation, neurite outgrowth and arborisation is concentration-dependent [35] and rapidly decreases expression of memory related receptors such as NMDA and EphB2 [33].

In ex vivo organotypic slices; physiological concentrations of $\mathrm{A} \beta$ dimers and trimers, but arguably not monomers, induce loss of hippocampal synapses, which requires the activation of NMDARs [36]. Sub-lethal levels of $A \beta$ decrease spine density, increase spine length and subdue spine motility [37]. Selective expression of APP in pre- or postsynaptic neurons, resulting in either dendritic or axonal $\mathrm{A} \beta$ overproduction, reduces spine density and plasticity at nearby dendrites [38]. Some molecular mechanisms of $\mathrm{A} \beta$-induced synaptic dysfunction and spine shrinkage in these in vitro and ex vivo paradigms have been suggested [39].

\section{Putative evidence that $A \beta$ can lead directly to synapse dysfunction in vivo}

Despite several technical limitations, arguably the most direct evidence supporting the role of $A \beta$ in synapse destruction in $\mathrm{AD}$ is that $\mathrm{A} \beta$ oligomers extracted from human $\mathrm{AD}$ brain inhibit long-term potentiation (LTP), enhance longterm depression (LTD), reduce dendritic spine density and disrupt memory and learning in vivo when directly injected into a mouse hippocampus [40]. Hippocampal injections of soluble $A \beta 42$ oligomers in vivo, in awake mice, stimulate AD pathology including neuronal loss, although this requires a regimen involving multiple injections of highly concentrated $A \beta$ [41]. Finally, transgenic mouse lines producing high levels of soluble $A \beta$ 
show age- and genotype dependent reductions in spine density [42].

\section{Is $A \beta$ the central cause of synapse destruction in $A D$ ?}

The aforementioned studies of $A \beta$ at synapses are difficult to interpret. $A \beta$ plaque deposition can occur without associated synapse loss [43], and conversely synapse and dendritic tree loss can occur in areas without $A \beta$ deposition, although synapse loss does usually appear exacerbated near $A \beta$ plaques [44]. Thus it would be prudent to treat the suggestion that $A \beta$ plaques have a primary causative role in synapse destruction in human LOAD with caution.

As for $A \beta$ oligomers however, while many reports identifying $A \beta$ oligomers as triggers of synaptic degeneration support the amyloid hypothesis, technical restrictions limit interpretations of these results, and their relevance to the human disease is unclear, as we discuss below. For example, are pathological effects in mice resulting from injection or over-expression of $A \beta$ relevant to the human condition?

Furthermore, synaptic gene dysregulation in early $\mathrm{AD}$ can occur independently of alterations in the expression of APP and regulators of APP metabolism [45]. Finally, genetic studies suggesting a role for APP and its processing in familial EOAD may have been incorrectly extrapolated to LOAD. Thus, as with plaques, it is conceivable that $A \beta$ oligomers play a role, but it would also be prudent to treat the suggestion $A \beta$ oligomers play a primary or sole causative role in synapse destruction with a degree of caution.

Later we discuss our view that understanding $\mathrm{AD}$ requires first understanding the complex biology of the multicellular synapses [46], the role of glia in synapse removal, and the means by which these cells can be driven towards excess synapse removal and/ or destruction.

\section{The Amyloid Hypothesis and Recent Drug Developments}

Since the literature on $\mathrm{AD}$ has been largely $\mathrm{A} \beta$-centric, myriad studies provide much reassurance that the amyloid hypothesis is on solid ground. As a result, the hypothesis has maintained supremacy in driving drug development efforts.

Much faith has been placed in AD mouse models, built on and embedded in the amyloid hypothesis, as the testing ground for new therapies. Beginning with a 1999 study by Schenk and colleagues [47], many studies show that amyloid removal relieves AD symptoms in mouse models of the disease. Since these mice produce human amyloid, both active and passive immunization strategies aimed at removing the putative causal $A \beta$, not surprisingly, reduce fibrillar amyloid and $A \beta$ plaque deposition, result in fewer neuritic lesions, and protect mice from cognitive decline [48]. Furthermore, inhibitors of the enzymes that cleave $A \beta$ from its membrane bound precursor have been therapeutically investigated both in mice and human studies (Table 1). Such positive outcomes rapidly led to Phase 1, 2 and 3 human trials.

\section{The amyloid hypothesis has so far failed clinically}

The Food and Drug Administration (FDA) has over the years approved five drugs for AD; Donepzil, Galantamine, Memantine, Rivastigimine and Tacrine. It is notable that each of these are unrelated to the amyloid hypothesis and were not tested in transgenic AD mice before being used in the clinic [66].

Meanwhile, many anti-amyloid treatments that were tested in mice have completed, or are undergoing, extensive clinical trials in humans. We summarise the most high profile of these drugs in Table 1 . They are divided into those directly targeting $A \beta$ by active and passive immunization, those targeting inhibition or modulation of the $\gamma$-secretase APP cleaving enzyme (Figure 2), presenilin, and those targeting the APP $\beta$-secretase cleavage enzyme BACE1.

So far, anti-A $\beta$ treatments have broadly failed to meet their primary clinical endpoints and some major phase 3 trials were halted early. None of the tested treatments have produced a discernible functional recovery, or altered the course of disease. In fact alarmingly some, specifically inhibitors of $\gamma$-secretase, lead to an increased decline in cognition (Table 1). With each successive failure the validity and foundations of the amyloid hypothesis, on which these drugs have been based, is called increasingly into question. Haste to run Phase 3 trials without Phase 2 success, and similar criticisms, have recently been made of this commerciallydriven enterprise [67].

Why is the hypothesis failing clinically? Some suggest the disease is not being targeted early enough [68], noting that in animal models anti- $\mathrm{A} \beta$ approaches clear hyperphosphorylated tau aggregates when given to young, but not old, animals [69] and, also, detailed analysis of recent trials have shown hints of treatment benefit in individuals treated early in disease [57].

Planned human intervention studies aim to address this issue in two ways. The DIAN [70] and the API Colombia study [71] use anti-A $\beta$ antibody treatments in presymptomatic individuals at risk for familial EOAD. If these trials succeed, the results will provide evidence for a degree of $A \beta$ involvement in EOAD. They will not necessarily prove $A \beta$ causality in all EOAD, nor will they provide information on the role of $A \beta$ in LOAD. 
Table 1 High profile clinical trials based on the amyloid hypothesis

\begin{tabular}{|c|c|c|c|c|c|}
\hline $\begin{array}{l}\text { Mechanism of } \\
\text { action }\end{array}$ & Drug name & $\begin{array}{l}\text { Clinical } \\
\text { phase }\end{array}$ & Key results from each trial & $\begin{array}{l}\text { Current status } \\
\text { (August 2014) }\end{array}$ & Reference \\
\hline \multirow[t]{4}{*}{$\begin{array}{l}\text { Active } \\
\text { immunisation } \\
\text { with } A \beta\end{array}$} & AN1792 & 2 & $\begin{array}{l}\text { Plaque Cleared. NFT reduced in neuronal processes, but not } \\
\text { cell bodies. Very few antibody responders (25/239). Reports of } \\
\text { encephalitis. }\end{array}$ & Discontinued & {$[49,50]$} \\
\hline & CAD106 & 2 & Favourable safety profile. Prolonged antibody titre in responders. & Ongoing & [51] \\
\hline & ACC001 & 2 & $\begin{array}{l}\text { Co-administration of adjuvant required for strong antibody response. } \\
\text { Generally safe and well-tolerated, no adverse related event. }\end{array}$ & Discontinued & [52] \\
\hline & AD02 & 2 & $\begin{array}{l}\text { Favourable safety and tolerability profile. Did not reach primary or } \\
\text { secondary outcome measures in phase } 2 \text {. }\end{array}$ & Ongoing & [53] \\
\hline \multirow{5}{*}{$\begin{array}{l}\text { Passive } \\
\text { immunization } \\
\text { against } A \beta\end{array}$} & Solanezumab & 3 & Worsening cognition compared to placebo, multiple adverse events. & Terminated & [54] \\
\hline & Bapinezmab & 3 & $\begin{array}{l}\text { Engaged target. Reduction in cerebrospinal fluid phospho-tau in APOE4 } \\
\text { carriers. Decreased rate of amyloid accumulation in APOE4 carriers. No } \\
\text { improvement in clinical outcomes in carrier or non-carriers of APOE4. } \\
\text { Negative amyloid scans in } 36 \% \text { of non-carriers. }\end{array}$ & Discontinued & [55] \\
\hline & Gantenerumab & $2 / 3$ & $\begin{array}{l}\text { Safe and well-tolerated at phase } 1 \text {. Focal inflammation in areas with } \\
\text { amyloid reduction a concern. Amyloid reductions compared to } \\
\text { placebo. }\end{array}$ & $\begin{array}{l}\text { Recruiting for } \\
\text { Phase } 3 \text { DIAN } \\
\text { trial }\end{array}$ & {$[56]$} \\
\hline & Crenezumab & 2 & $\begin{array}{l}\text { Did not meet co-primary endpoints. Trend of improved cognition in } \\
\text { people with mild disease. }\end{array}$ & Ongoing & [57] \\
\hline & Ponezumab & 2 & $\begin{array}{l}\text { Safe and well-tolerated at phase 1. Plasma Aß40 increased at phase } 2 \text {. } \\
\text { No effect on primary endpoints in phase } 2 .\end{array}$ & $\begin{array}{l}\text { Recruiting for } \\
\text { further Phase } 2 \\
\text { trials }\end{array}$ & [58] \\
\hline \multirow[t]{2}{*}{$\begin{array}{l}\text { Y-Secretase } \\
\text { inhibitors }\end{array}$} & Avagacestat & 2 & $\begin{array}{l}\text { Gastrointestinal and dermatological side effects at Phase 1. Also } \\
\text { dose-dependent pharmacodynamic effects on CSF biomarkers in } \\
\text { some patients. Trend towards worsening cognition at higher doses } \\
\text { compared to placebo. Amyloid related imaging abnormalities. }\end{array}$ & Discontinued & [59] \\
\hline & Semagacestat & 3 & $\begin{array}{l}\text { Dose-dependent reduction in } A \beta \text { synthesis at Phase } 1 \text {. Reduced plasma } \\
A \beta \text { at Phase } 2 \text {, but no differences in cognition. No improvement in } \\
\text { cognition and worsening cognition at higher doses compared to controls at } \\
\text { Phase } 3 .\end{array}$ & Discontinued & {$[60]$} \\
\hline \multirow[t]{3}{*}{$\begin{array}{l}\text { Y-Secretase } \\
\text { modulators }\end{array}$} & CHF5074 & 2 & $\begin{array}{l}\text { Anti-inflammatory at Phase 2. Trend towards improved function in APOE } 4 \\
\text { carriers. }\end{array}$ & Ongoing & [61] \\
\hline & EVP-0962 & 2 & Does not inhibit cleavage of $\gamma$-secretase substrates other than APP. & Ongoing & [62] \\
\hline & Tarenflurbil & 3 & $\begin{array}{l}\text { Small functional benefit at higher doses in mild AD but no cognitive } \\
\text { benefit at Phase 2. No changes in CSF A } 342 \text {. Failed to meet primary } \\
\text { and secondary endpoints at phase } 3 \text {. }\end{array}$ & Discontinued & [63] \\
\hline \multirow[t]{2}{*}{$\begin{array}{l}\beta \text {-Secretase } \\
\text { modulators }\end{array}$} & MK-8931 & 3 & Reduced CSF A $\beta$ compared to controls. Safe and tolerable at Phase 2. & $\begin{array}{l}\text { Recruiting for } \\
\text { Phase } 3\end{array}$ & [64] \\
\hline & CTS-21166 & 1 & Dose dependent reduction in plasma $A \beta$. & Completed & [65] \\
\hline
\end{tabular}

The Anti-A $\beta$ asymptomatic Alzheimer's disease trial [72] meanwhile tests the effect of starting anti-A $\beta$ treatment at the pre-symptomatic stage, in individuals predicted to develop LOAD on the basis of brain amyloid accumulation as measured by positron emission tomography (PET) imaging. This will effectively test the hypothesis that anti-A $\beta$ treatments provide cognitive benefits when given earlier in sporadic AD.

Another prominent suggested reason for clinical failures of anti- $A \beta$ drugs in particular are that the agents used initially were not properly validated and were flawed [68]. A recent study has shown the monoclonal anti- $\mathrm{A} \beta$ antibodies, solanezumab and crenezumab, fail to target human $A \beta$ as effectively as they target over-expressed human $A \beta$ in mouse models [73]. The possibility was also countenanced that only amyloid plaques, potentially functionally inert [74], rather than soluble $A \beta$ oligomers were targeted in early trials. Furthermore monotherapies may not be capable of effectively reducing $A \beta$ plaque load. A double pronged approach to reduce $A \beta$ by both active immunisation and inhibition of $\beta$-secretase has effectively cleared plaques in mice [75]. However, as reviewed recently [67], therapeutic approaches targeting plaque and approaches targeting soluble $A \beta$ have both now been tested in humans, with equally negative outcomes.

Whilst the latter conclusions suggest that anti-A $\beta$ treatments may be failing because they poorly target $A \beta$ in human tissue, the conclusion does not disprove an alternative view for the failure of clinical trials, namely that $A \beta$ is not responsible for all $A D$. Indeed for some 
the failure of clinical trials was by no means a surprise [76] and the validation that bapineuzumab does effectively bind $A \beta$ in human tissue [73], but did not provide recovery in clinical trials, only provides support for this view. In the following sections we elaborate on the notion the central focus on $A \beta$ is, on the available evidence, unwarranted.

\section{Evidence Supporting the Amyloid Hypothesis is Equivocal}

\section{The $A \beta$ deposition paradox}

"How wonderful that we have met with a paradox. Now we have some hope of making progress."

\section{- Niels Bohr}

\section{A $\beta$ deposition occurs in cognitively normal individuals}

Up to $40 \%$ of non-demented elderly can reach some level of neuropathological criteria for $\mathrm{AD}$ [77]. A positive correlation also exists between $A \beta$ deposits and increases in phosphorylated tau, the other major cerebral histological inclusion in AD protein, in cognitively normal patients [78]. In one study only $17 \%$ of cognitively normal elderly patients had few or no degenerative brain changes [79], and in neuroimaging amyloid-PET studies $10-30 \%$ of cognitively normal individuals have amyloidpositive scans [80]. Around $50 \%$ of people over the age of 85 have $\mathrm{AD}$ [81], rising to $77.5 \%$ of centenarians who meet criteria for mild confusion or severe dementia based on cognitive testing [82]. This could be interpreted to suggest that amyloid deposition is predominantly associated with normal aging and is not a disease per se.

Not only does this paradox create difficulty for diagnosing disease by $\mathrm{A} \beta$ plaque deposition, it remains awkward for the amyloid hypothesis. It is suggested that individuals with high plaque burden, but are cognitively normal, are in a pre-clinical AD stage [83], since the progression of mild-cognitive impairment to $\mathrm{AD}$ is associated with the $A \beta$ deposits [84]. However recent in vivo imaging techniques illustrate that some nondemented patients can have plaque burdens equivalent to those seen in demented patients [85], and amyloid deposition commonly plateaus, despite declining cognition [86]. In contrast, other markers of advancing AD pathogenesis such as synaptic loss, NFTs, and microglial activation correlate with the course of disease [87]. Conversely, neurodegeneration can appear independently of plaque deposition [88]. Notably too, individuals with Trisomy 21 (Down's syndrome), who have a triple copy of $A P P$ universally have elevated $\mathrm{A} \beta$ and diffuse non-fibrillar plaques that begin developing as early as 8 years of age, yet they do not necessarily develop dementia by their 70s [13]. Thus, the link between $A \beta$ deposits and causality remains uncertain.

In sum, the distribution of amyloid deposits in the brain does not correlate well with neuropathology, loss of neural function from specific brain areas, or cognitive impairment. A conclusion that plaque is not the cause of LOAD provides one possible explanation for $A \beta$ vaccination trials not improving patient outcome, even when plaque was removed.

\section{Why are plaques present in cognitively normal individuals?}

Several valid interpretations of AD data could equally explain the $A \beta$ deposition paradox:

1. The type of plaque is important for cognitive decline. Plaques can be either diffuse, fibrillar or dense cored, and fibrillar amyloid plaques may represent the toxic plaque in the AD brain [89]. Some suggest a rise in fibrillar plaque load is correlated to dementia [90], but both diffuse and fibrillar plaques exist in cognitively normal people [91] and in any event plaques are questioned as a cause of cognitive deficits [92].

2. Plaques may be non-toxic, but could become toxic when bound to metal ions [93].

3. Some individuals may have a 'cognitive reserve', a hypothetical concept described as accumulating over a lifespan, allowing them to cope with more amyloid [94].

4. Amyloid fibrils may be biologically inert [74] casting doubt over the role of these lesions in the AD brain.

5. Amyloid plaques are not the cause of $\mathrm{AD}$, rather it is soluble A $\beta$ oligomers, a theory with limitations (discussed in detail below).

6. Another possibility, difficult to resolve, is that A $\beta$ plaque load contributes in only some cases of $\mathrm{AD}$, together with the simply corollary that it has little to do with outcome in many cases of the diseases.

7. Plaques could be an occasional by-product of APP cleavage with variable, if any, mechanistic consequence.

8. Plaques may be formed for a purpose, as a cerebral blood vessel sealant to maintain vascular supply to the brain during aging [95]. The implications of reduced clearance of brain $A \beta$ and the presence of amyloid plaques in the cerebral vasculature are reviewed in depth elsewhere [96].

Causal or not, why do $A \beta$ plaques accumulate? Studies of EOAD mutations suggest they arise from increased cleavage of longer, more amyloidogenic forms of $A \beta$. 
However, this does not explain $\mathrm{A} \beta$ plaques in LOAD cases lacking EOAD mutations, and in non-demented individuals. Failed clearance of $A \beta$ via reduced levels of A $\beta$ cleaving enzymes such as neprilysin [97] and insulindegrading enzyme [98] may allow plaque to accumulate. Also, the risk allele APOE4 may relate to reduced $\mathrm{A} \beta$ clearance from the brain [99]. Whilst used as evidence for the amyloid hypothesis, these latter explanations for plaque accumulation also fit with the other plausible explanations for plaque accumulation outlined above.

\section{The rise of the soluble $A \beta$ hypothesis}

Rather than considering that the unreliability of plaque as a disease marker may reflect badly on the amyloid hypothesis, its guardians embraced soluble $A \beta$ oligomers as a cause of $\mathrm{AD}$ [100]. Yet, as we elaborate in the next section, concerns have been voiced about the oligomer hypothesis. These include a suggestion the amyloid hypothesis is "...that invisible molecules target invisible structures" [101], with new information interpreted within a constantly fluctuating amyloid hypothesis, rather than being molded into alternative hypothesis which may better explain disease causality. Regardless, the amyloid hypothesis has shifted in recent years to suggest soluble $\mathrm{A} \beta$ oligomers, rather than plaques, are responsible for neurodegeneration.

\section{Uncertainty surrounding the presence of $A \beta$ oligomers in vivo}

Oligomers are seen in the brain tissue of $\mathrm{AD}$ mouse models, although this does not correlate with cognitive decline [102]. Nevertheless, in one study oligomers were found in post-mortem human $\mathrm{AD}$ brains but not cognitively normal controls [40]. Furthermore, oligomers appeared to differentiate $\mathrm{AD}$, dementia without $\mathrm{AD}$ pathology and cognitively normal patients in another [103]. This evidence is much cited in support of a role for oligomers in $\mathrm{AD}$, but the data fail to define clearly which manifestation of many possible $A \beta$ oligomers are toxic, or if $A \beta$ oligomers are responsible for toxicity [104].

Debate also continues over the nature of amyloid assemblies in vivo, with studies reporting various assemblies showing different toxic effects (reviewed in [105]). Moreover, at present it is only possible to study $A \beta$ oligomers secreted from in vitro cultures, or extracted from postmortem brain tissue $[105,106]$. Accordingly, some have inferred current evidence for $A \beta$ oligomerisation may simply be an artifactual consequence of detection techniques such as sodium dodecyl sulphate (SDS) polyacrylamide gel electrophoresis (PAGE) [107]. Hence it is not yet clear if $\mathrm{A} \beta$ oligomers are present in the original tissue, or rather arise due to experimental manipulations.

For example, SDS-PAGE can detect A $\beta$ oligomers in human brain homogenates, yet surface-enhanced laser desorption/ionization time-of-flight MS (SELDI-TOF MS), which requires less manipulation of samples prior to analysis, fails to detect dimeric $A \beta$ in human brain homogenates [107]. Both SDS-PAGE and SELDI-TOF MS could detect $A \beta$ monomers from human brain homogenate. As the authors note, this suggest an overreliance on low-resolution techniques, such as immunoblotting, may have distorted our understanding of $\mathrm{A} \beta$ biochemistry in the in vivo human brain. Clearly, our understanding of the true biochemistry and presence of A $\beta$ monomers, dimers and higher order oligomers in the human brain in vivo is limited. Unfortunately, data that brought the amyloid hypothesis to its current, $A \beta$ oligomer-based state, including the aspects concerning synaptotoxicity, arose from material driven by such low-resolution techniques.

\section{Studying $A \beta$ oligomer toxicity in vivo is methodologically difficult}

As we have discussed above, support for a role of $\mathrm{A} \beta$-oligomers in $\mathrm{AD}$ derives from experiments showing that injection of oligomers into the brain causes deficits in synaptic plasticity, learning and memory, and reduces synaptic spine density. However, there are several methodological aspects of these experiments which give cause for concern:

1. Some studies involve injection of synthetically derived peptides into the rodent brain, that were first crystallised into oligomers in vitro. These synthetically-derived peptides lack post-translation modifications, and may be different from $\mathrm{A} \beta$ peptides produced in the human brain [108].

2. In humans $A \beta$ oligomers associate with lipoproteins, which may prevent $A \beta$-related toxicity, whereas synthetically derived $A \beta$ are applied without these lipoproteins [109]. Clearly, this questions their physiological relevance.

3. Oligomerisation of $A \beta$ may be stimulated by its adherence to the implanted plastic pumps used to deliver peptides [41].

4. The physiological relevance of injecting a bolus dose of either synthetically or human derived $A \beta$-oligomers into an intact rodent brain is doubtful, since this experimental protocol scarcely mimics the deposition of $\mathrm{A} \beta$ in vivo [110].

Clearly, models for testing $\mathrm{A} \beta$ oligomer toxicity in vivo must be considered in the context of our limited understanding of $\mathrm{A} \beta$ oligomer biology in vivo and in the context of technical limitations summarised above. Data from these studies cannot yet be confidently interpreted to elucidate the pathogenic mechanisms occurring in the human brain. 
The role of $A \beta$ oligomers in $A D$ pathogenesis is uncertain

In sum, the doubts associated with $A \beta$ plaques have driven the field towards considering oligomers as the central toxic species. However, a new set of problems arise from a lack of unequivocal evidence that $A \beta$ oligomers are toxic in vivo [104]. There is yet to be a study convincingly establishing a relationship between specific conformations of oligomers and the initiation of disease in vivo, clearly in part due to methodological difficulties. Conflicting data from separate groups must be reconciled to gain a true understanding of $A \beta$ biology in the normal and diseased brain. Standardising experimental protocols for identifying $A \beta$ species is an important first step [111]. At this stage, a harsh interpretation is that perceived $A \beta$ toxicity may represent experimental artefact rather than the true function of $\mathrm{A} \beta$ in vivo during the disease process. More likely, the role of $A \beta$, in whatever forms it is active, will surely ultimately need to fit into a broadened holistic view of disease.

\section{Key Observations in Human AD are Poorly Understood and Poorly Modelled}

$A D$ symptoms and pathology are heterogeneous

The similarities between EOAD and LOAD pathology are integral to the amyloid hypothesis. Yet, both LOAD and familial EOAD are highly heterogeneous. They exhibit (1) different ages of onset [112], (2) differing temporal progressions [113], (3) different and varying cognitive symptoms [114] and (4) dissimilar pathological presentations [115].

Furthermore, a third of patients with EOAD show non-memory symptoms, whilst in LOAD only $6 \%$ have non-memory symptoms [116]. In twins environmental influences play a part in the timing of onset and on the levels of pathological markers at the end stage [117]. This heterogeneity has been recognised in recent $\mathrm{AD}$ diagnostic guidelines from the National Institute on Aging (NIA) and Alzheimer's Association (AA) [118].

Important to note also is that although essentially $100 \%$ of individuals with Down's syndrome have neuritic fibrillar plaques and NFTs by the fifth decade, the onset of dementia is highly variable, with only $70 \%$ becoming demented by their 70s, but with most maintaining their baseline cognitive abilities through their $40 \mathrm{~s}$ and into older ages [13].

\section{AD brains show mixed pathological presentations}

Regional aggregation of $A \beta$ may differ in familial and sporadic cases. Remarkably, amyloid deposition is actually greater in some regions in sporadic $A D$ cases than in early onset cases with presenilin mutations [119], indicating not all cases of AD follow the same distinct pattern of amyloid deposition as suggested in 2002 [120]. This observation alone raises doubt that the clinical phenotype of $A D$ is solely related to $A \beta$ deposition.

Furthermore, up to $50 \%$ of $\mathrm{AD}$ cases have mixed pathologies with other neurodegenerative conditions. For instance, $\alpha$-synuclein deposition (otherwise seen in Lewy bodies), is a common co-morbidity with amyloid deposition, with more than $50 \%$ of AD patients also exhibiting $\alpha$-synuclein accumulation [121].

Many consider disease heterogeneity as the manifestation of human genetic variation and environmental factors influencing progression of an $\mathrm{A} \beta$ or a tau-driven disease. Animal models provide support for this view, since they show homogeneous disease phenotypes, where variation can be introduced through environmental actions such as exercise and environmental enrichment and through mouse strain genetic background, providing a model for the amyloid hypothesis. However, as we shall next discuss, animal models may not truly reflect either LOAD, or even all cases of EOAD. A real possibility, instead, is that human AD may be heterogeneous in presentation because the causes of $\mathrm{AD}$ may be heterogeneous, causing the diversity of symptoms that characterise the disease.

\section{Pre-clinical AD models are not representative of human disease}

Almost all mouse models of $\mathrm{AD}$ are engineered to over-express human APP to such an extreme extent that animals show pathology within months of birth. The treatments in current human testing have usually been shown to alter this pathology before being developed for the clinic. However, this approach has yet to produce a result that has translated to a positive human clinical outcome [66].

Little evidence indicates that APP is overexpressed in the human $\mathrm{AD}$ brain [122]. Indeed, total $\mathrm{A} \beta$ may be reduced [123]. More worrying, most mouse models do not show substantial neuronal loss, despite the presence of large depositions of amyloid [124]. Further, in contrast to human $\mathrm{AD}$, where synapse loss is integral, mice show a highly variable presentation. Some mice show increased synaptic density in specific brain regions, while most models show reduced synaptic density.

Thus, while providing reasonable models for assessing the ability of a treatment to remove $A \beta$ in vivo, and for investigating the relationship of $A \beta$ to other features of the disease, such as its inflammatory components [125], the reality is that removing an overexpressed $A \beta$ molecule in these mice may not be relevant to removing an under expressed, but aggregated molecule, from the human brain. Additionally, a number of questions 
remain as to the relevance of these transgenic mice to human AD:

1. Overexpression of wild-type APP, rather than mutant human APP, can cause memory impairments in mice independently of amyloid deposition [126,127]. APP overexpression may therefore only model rare forms of $\mathrm{AD}$ in which APP locus duplication is linked to EOAD [128]. Such duplication is associated with a very limited number of early-onset cases $[129,130]$. This questions the validity of mice overexpressing mutant APP. Further, it raises concerns about controls used in most mouse experiments; i.e. studies of age-related cognitive decline should use mice expressing wild-type APP at comparable levels to over-expressed mutant-APP, alongside the commonly used non-transgenic wild-types as controls, but usually do not [131].

2. Despite increases in amyloid, a number of mouse studies failed to detect any cognitive abnormalities [132]. For example, mouse models expressing familial AD-related mutant APP revealed no cognitive deficits [133]. Remarkably, in one report, overexpression of mutant human protein actually improved the cognitive performance relative to controls [134].

3. Mouse models of $\mathrm{AD}$ deposit peptides that are distinct from those found in the human brain, an important consideration in the design of drugs targeting A $\beta$ removal $[135,136]$.

4. The phenotype of AD mouse models varies depending on the background strain used, and can affect the outcome of drug studies [137]. Prudence therefore requires drugs to be investigated in multiple mouse lines and models, but this is not often done.

5. A related concern is that cognitive testing of mice requires updating [138].

6. While expressing the human APP gene, genetic animal models of AD also express endogenous, non-human APP. A critical question remains as to the role of endogenous mouse amyloid and APP in these models. Evidence suggests that the endogenous protein has an essential role in learning but this has barely been studied [139]. If true then removing endogenous $A \beta$ in these mice, and indeed in humans, may have detrimental effects on memory, thereby contributing to the very problem they are designed to treat.

7. Both EOAD and LOAD are pathologically heterogeneous and many non-genetic risk factors for disease also exist, for instance Type II diabetes. Mouse models poorly represent these features of human AD.

\section{Development of novel pre-clinic models to improve translation of drugs to the clinic}

Given the limitations of the mouse models, several groups have attempted to investigate alternatives. This includes other species that may better recapitulate AD pathology including rats, octodon degu, chicks, dogs, guinea pigs, rabbits, dolphins and non-human primates, although these are much more expensive to investigate and some still rely on APP over-expression.

Notable exceptions to the over-expressing mouse models include the senescence accelerated mouse model (SAMP8) [140] and the anti-NGF mouse [141]. These latter models replicate several features of $\mathrm{AD}$ without relying on human familial mutations. Others have used mice with inducible neuronal loss to replicate the patterns of loss seen in human AD [142]. Stimulation of inflammation also recapitulates many $\mathrm{AD}$ features in mice, including increased levels of cleaved APP fragments, altered tau phosphorylation [143] and declining motor and cognitive skills.

Recently a more relevant mouse model was created in which humanized $\mathrm{A} \beta$, with human $\mathrm{AD}$-causing mutations, was inserted into endogenous mouse APP [144]. These mice showed $A \beta$ pathology, neuroinflammation and memory impairment, although there was an absence of tau pathology. This study supports a role for mutant APP (but not necessarily for $\mathrm{A} \beta$ per se) in some familial forms of disease. It does not however show $\mathrm{A} \beta$ causality in more common sporadic forms of disease. It is also prudent to recall that the majority of familial cases of $\mathrm{AD}$ are linked to mutations in presenilin genes, rather than mutations in $A P P$, which are rare [145].

We are intrigued by the highly relevant modelling of $\mathrm{AD}$ based on other risk factors of disease. For example, diabetic mice develop many similar features to AD mice [146] and a mouse model of chronic heart failure shows alterations in the metabolism of cerebral $A \beta$ and cognitive impairments [147]. These mouse models show it is not necessary to have familial AD mutations, nor do they need to have the aggregating form of amyloid, to re-create several features of disease. However in general, at this stage, the genetic mouse models hold front and center stage in AD studies. Studies based on these need to be increasingly treated with caution and consideration given to the use of different models.

\section{Genetics Paint a Complex Picture of AD Pathogenesis Beyond $A \beta$}

\section{A complex picture indeed}

It is widely accepted that $A \beta$, when injected or overexpressed in substantial excess, can cause pathology in rodents, but what is the scenario by which genetic mutations in the human cause AD? APP trafficking, function and cleavage is complex and highly controlled. We show in this section that mutations in APP can cause changes to a 
range of APP cleavage products, all of which could affect synaptic function. Meanwhile, presenilin mutations impact the cleavage of numerous proteins also with synaptic functions. Thus, even in EOAD caused by mutations in APP or presenilin, $A \beta$ may not be the sole basis of disease. In sum, a valid, but inconvenient interpretation of AD genetics is that the aberrant processing of APP, or of other proteins cleaved by presenilin containing enzymes, is the key contributing factor in familial AD, rather than solely aberrant production of $\mathrm{A} \beta$ that contributes to histopathology. Furthermore, as we first discuss below, given the numerous genes and processes implicated in AD, it seems highly unlikely that any single gene such as APP alone will account for this disease in the majority of AD cases.

\section{The genetic risk factors for AD are many and varied}

Genome-wide association studies (GWAS) have identified a number of genetic risk factors for AD. To date, the most emphatic demonstration that numerous genes contribute to the risk of $\mathrm{AD}$ has come from a meta-analysis of four GWAS data sets consisting of 17,008 AD cases and 37,154 controls from 15 countries [148], which implicated 11 new regions of the genome as risk factors for $\mathrm{AD}$. The findings reinforce the importance of the innate immune response and inflammation (HLA-DRB5/DRB1, INPP5D, $M E F 2 C)$ already implied by previous work (CR1, TREM2). Also reinforced is the importance of cell migration (PTK2B), lipid transport and endocytosis (SORL1). New hypotheses on $\mathrm{AD}$ pathogenesis have also emerged related to genetic mutations in molecules associated with hippocampal synapse function $(M E F 2 C, P T K 2 B)$, the cytoskeleton and axonal transport (CELF1, NME8, CASS4) as well as myeloid and microglial cell functions (INPP5D). While efforts are often made to relate new data to the amyloid hypothesis [149], many of these mutations are not conveniently placed within it.

Furthermore, new research showing the molecular signatures of $\mathrm{AD}$ vs. normal aging indicates that the molecular phenotype of $\mathrm{AD}$ is highly complex, with a variety of transcriptional changes differentiating $\mathrm{AD}$ from aging. Transcriptional profiles for neuroinflammatory and lipid metabolism genes in particular are altered early in disease in this dataset [150].

GWAS and ageing data is therefore increasingly consistent with a view that $A \beta$ (or more likely altered APP production, function and cleavage) exists somewhere within a highly complex disease framework that is yet to be understood. It is unclear whether numerous mechanisms converge on a single primary pathway, or, if $\mathrm{AD}$ will need to be redefined as a host of diseases manifesting ultimately as memory loss, resulting from synapse loss and neurodegeneration. The latter view, that memory becomes problematic when brain function is disrupted, has simple appeal, but is a nightmare from a therapeutic perspective.

\section{Mutations in presenilin genes do not always increase $A \beta$ cleavage}

There is a widespread assumption that all the genetic links to $\mathrm{AD}$ effectively modify the cleavage of $\mathrm{A} \beta$ to produce more of the longer forms, $A \beta 42$ and $A \beta 43$, or increase the ratio of longer $A \beta$ peptides compared to shorter ones and in turn that this is causative of AD. Certainly, evidence for increased levels of $A \beta 42$, or for increases in the $\mathrm{A} \beta 42: \mathrm{A} \beta 40$ ratio as a result of APP, PSEN1 and PSEN2 mutations has been found in both in vivo and in vitro studies [151-153]. However the conclusion is not warranted in view of the full data set.

In a study examining the effects of eight FAD PSEN1 mutations on $\mathrm{A} \beta$ production, most of the mutants produce no change in the $A \beta 42: 40$ ratio [154]. Furthermore, family members with the same FAD mutations exhibit heterogeneity in their clinical and neuropathological phenotypes [155]. These results are supported by studies showing heterogeneous effects of FAD PSEN mutations on the $A \beta 42: 40$ ratio depending on the mutation [156-158], but are contradicted by reports of universal increases in A $\beta 42$ as a result of FAD mutations [153,159]. Nevertheless as it stands, it seems unlikely that FAD mutations lead to the same phenotypic amyloid cleavage, resulting in increased $A \beta 42$ and/or increases in the $A \beta 42: 40$ ratio.

Newer evidence for the role of a longer form of $A \beta$, $\mathrm{A} \beta 43$, in disease pathogenesis may be the result of a familial AD-linked presenilin mutation [160]. The A $\beta 43$ : $\mathrm{A} \beta 42$ ratio is increased in mice harbouring this particular presenilin mutation, with no change in A $\beta 40$ or $A \beta 42$ levels [160]. We simply cannot draw conclusions at this stage about the role of any form of $A \beta$ in disease. It would be prudent to include measurements of a variety of $A \beta$ cleavage forms in disease, and determine the importance of qualitative versus quantitative changes in $A \beta$ production over time, during disease [161].

\section{Presenilin has important physiological functions independent of $A \beta$ cleavage}

Evidence from rare clinical case studies illustrates mutations in presenilin genes can be associated with neurodegeneration independently of amyloid plaque deposition. Presenilin mutations have been found in frontotemporal lobe dementia (FTD) without amyloid pathology [162], dementia with Lewy bodies [163], posterior cortical atrophy dementia [164] and atypical dementia [165]. However newer evidence suggests presenilin mutations may not be the true causes of all these amyloid-independent neurodegenerative states, as genetic defects in the progranulin (PGRN) gene can explain FTD, atypical phenotypes and parkinsonism, also associated with presenilin mutations $[166,167]$. There is however at least one clinical case involving a point mutation in PSEN1, that is associated with 
the development of Pick's disease with tauopathy, but without amyloid plaques [168].

Regardless, in $\mathrm{AD}$, where amyloid plaques are present, there is good reason to suggest that the effects of presenilin mutations on APP biology may account only in part, if at all, for the AD pathology they associate with. In fact, there are several known functions for presenilin which could be impacted by FAD-linked presenilin mutations. These alternative functions include roles in macroautophagy, APP vesicle transport, cell survival, cleavage of a wide variety of possible substrates, and the importance of presenilin for synaptic function, which together have culminated in the presenilin hypothesis of $\mathrm{AD}$ [169]. There are also links between presenilin function and the innate immune system, which may account for the presence of neuroinflammation in EOAD, independently of amyloid [170]. The numerous effects FADlinked presenilin mutations would have on all these processes could together account for AD independently of, or additional to, any effect on amyloid pathology.

\section{The Presenilin hypothesis of AD}

A 'presenilin hypothesis' of $\mathrm{AD}$ has been articulated [169]. We further suggest that presenilin mutations fit best within a hypothesis that AD is a disease driven by synapse loss. Though the AD literature has largely focused on the role of PSEN1 in APP cleavage (Figure 2), presenilin mutations affect a range of proteins and therefore processes, particularly those involved in synaptic function, as summarised above. Given that presenilin appears important for cleaving proteins that are crucial at synapses, presenilin mutations would lead to synaptic dysfunction. It would also follow that drugs targeting presenilin in humans are destined to have profound detrimental effects on the brain with longterm use. This indeed was the result of recent clinical trials of presenilin antagonists, also termed $\gamma$-secretase inhibitors (Table 1).

Nevertheless $\gamma$-secretase inhibition continues to be pursued. Recent evidence using conditional presenilin KOs has suggested that presenilin function is not as critical in the adult brain as the developing brain, allowing the field to justify its ongoing use as a target for drug intervention (See [171] for a detailed review). This is in spite of the reservations that emerge from consideration of data reviewed above.

\section{APOE4 dysfunction is related to inflammation}

The APOE4 allele has been a known genetic risk factor for sporadic $\mathrm{AD}$, and it remains the strongest known [22]. It has been linked to the amyloid hypothesis by indications it is involved in the clearance pathway of $A \beta$, with deficits causing a toxic $A \beta$ accumulation and aggregation [172]. Meanwhile, an alternative avenue of enquiry shows that APOE4 has intimate connections with innate immunity, and this was reasoned to explain its broader relationship with inflammatory disease, not just AD. One observation is that APOE suppresses TNF secretion from inflammatory cells [173] (also see [174]). Importantly an APOE mimetic that suppresses TNF secretion has successfully treated experimental models of neurodegenerative disease, including traumatic brain injury [175], stroke [176] and $\mathrm{AD}$ [177]. As well as reducing behavioral deficits, in the study of AD, the APOE mimetic also reduced $A \beta$ plaques and tau tangles [177]. The relationship of APOE4 to inflammation therefore opens a channel of enquiry directed to explain why stimulation of APOE expression in mice enhances normal $A \beta$ clearance (both soluble oligomers and plaques) and reverses behavioural deficits. In line with the observation of the link between presenilin mutations and inflammation, the links between APOE4 and inflammation further point to inflammation as a major player in $\mathrm{AD}$ pathogenesis independently of $A \beta$.

\section{Understanding the complexity of APP biology independently of $A \beta$ is important to understanding $A D$ pathogenesis}

APP synthesis, trafficking and cleavage are complex and highly regulated processes (Figure 2). It is important to recognise that familial $A D A P P$ and presenilin mutations may not only impact $A \beta$ production, but also the production of the other peptides produced from APP including sAPP $\alpha, \operatorname{sAPP} \beta, p 3$ and AICD, as well as the relative levels of full-length APP. Interestingly, overexpression of AICD can cause an AD-like phenotype [178], whilst increased cleavage of sAPP $\beta$ is associated with familial Danish Dementia with similar aetiology to AD [179]. Furthermore lowered levels of neurotrophic sAPP $\alpha$ are seen in AD, and mutations which inhibit the $\alpha$-secretase enzyme ADAM10, which liberates SAPP $\alpha$ from its precursor, are found in the promoter region and coding sequence of some individuals with AD [180]. Depletion of sAPPa by inhibition of ADAM10 trafficking can bring about sporadic AD phenotypes [181], corroborating an independent role for APP cleavage products other than A $\beta$ in bringing about disease phenotypes.

Whilst the functions of $\mathrm{p} 3$ and $\operatorname{sAPP} \beta$ are little explored (which in itself is a remarkable reflection of the intense focus on $A \beta$ at the expense of other cleavage products of APP), a wealth of evidence exists for physiological functions of sAPP $\alpha, A \beta$, AICD and full-length APP [182] (Figure 2). These studies raise questions as to whether familial $\mathrm{AD}$ driven by presenilin and APP mutations is primarily a result of aberrant $A \beta$ expression, or if it is in fact a result of altered APP cleavage, and the resultant effects of altered APP cleavage on sAPP $\alpha$, sAPP $\beta$, $\mathrm{A} \beta, \mathrm{AICD}, \mathrm{p} 3$ and full-length APP. This brief discussion 
does not even approach the possible physiological functions of C83, C99 (Figure 2), the different functions of the multiple isoforms of APP including $\mathrm{APP}_{695}, \mathrm{APP}_{751}$ and $\mathrm{APP}_{770}$, or the highly homologous proteins to APP, APLP1 and APLP2, which are also physiologically expressed in the human brain and may serve redundant functions with APP proteins.

\section{There are many unresolved issues in the amyloid hypothesis}

The field has pursued the idea that $A \beta$ accumulation is the central cause of AD based in part on an amyloidcentric interpretation of the genetics. Yet as described above, numerous products of APP are affected by APP mutations and by presenilin mutations.

One valid conclusion, in view of the complex biology of APP function and cleavage, is that APP and presenilin mutations cause AD because they alter several cleavage products of APP, which each in turn contribute to AD. In this view of disease, alterations in $A \beta$ expression would only be a part player in pathology or, perhaps even, a by-product, and an indicator of altered APP function and cleavage. This conclusion, if true, would predict that clinical trials of anti-A $\beta$ drugs will fail even in some or all cases of EOAD.

Meanwhile, analysis of the effects of presenilin mutations does not lead to the conclusion that $\mathrm{AD}$ is caused by $A \beta$. The cleavage of a range of proteins is affected by presenilin mutations and many would affect the synapse. In fact as we illustrated, presenilin mutations do not always alter $\mathrm{A} \beta$ production as may be expected. Finally, many mutations and risk factors associated with $\mathrm{AD}$ may not relate to $\mathrm{A} \beta$ metabolism.

Yet, amyloid-centric interpretations continue to flourish. A recent study showed that a mutation, determined to modestly decrease $A \beta$ levels of the course of lifespan, is preventative of $\mathrm{AD}$ [23]. This data was taken to suggest that a life-long reduction in $\mathrm{A} \beta$ reduces the risk of AD. However, the mutation also results in marginally (albeit non-significant) increases in levels of beneficial neurotrophic sAPP $\alpha$. Regardless, an alternative interpretation is that a life-long change in APP function and cleavage could protect against AD independently of lowered $\mathrm{A} \beta$ production.

\section{Future Directions}

\section{The emergence of more holistic approaches to} understanding $A D$ pathogenesis

As suggested by Figure 3, the amyloid hypothesis is at least incomplete, and quite possibly largely incorrect. Therefore it follows that therapies targeting A $\beta$ or APP processing may not treat $\mathrm{LOAD}$, and possibly may not even work in some cases of EOAD. Given this conclusion, it is worthwhile to consider alternative possibilities.

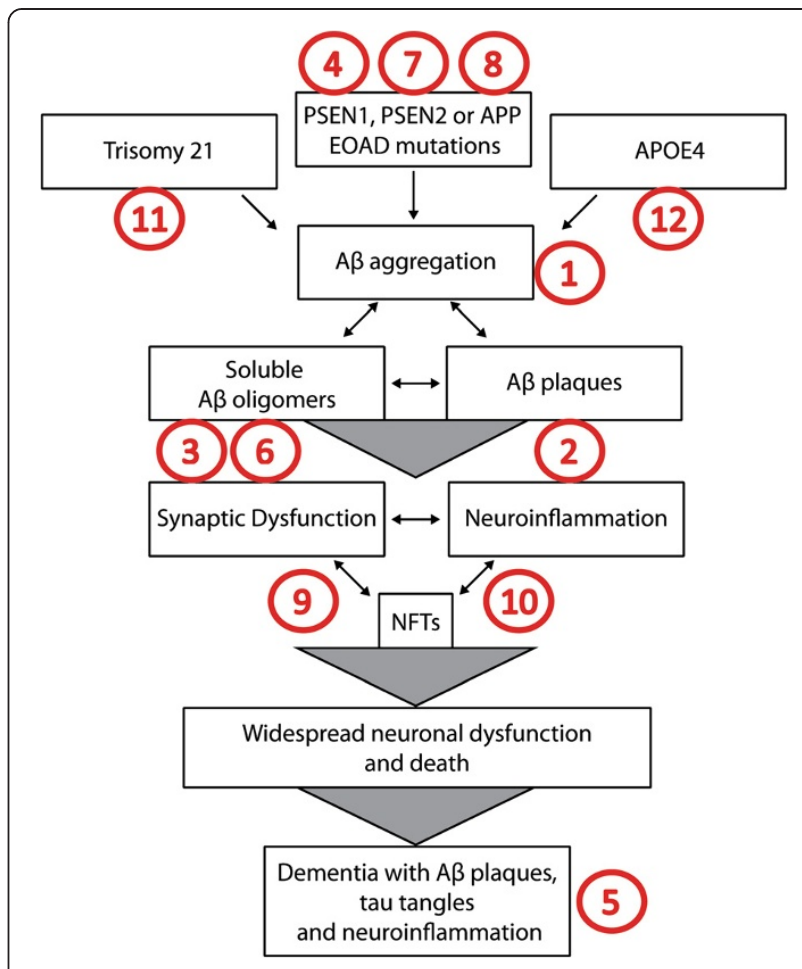

Figure 3 Controversies and Inconsistencies Within the Current Amyloid Hypothesis. 1. A $\beta$ deposition occurs in cognitively normal individuals; 2 . There is a weak correlation between plaque load and cognition; 3. The biochemical nature and presence of $A \beta$ oligomeric assemblies in vivo is unclear; 4. Pre-clinical AD models based on EOAD-linked mutations are biased toward the amyloid hypothesis; 5. Pathological heterogeneity and comorbidities are unexplained by the amyloid hypothesis; $\mathbf{6}$. A $\beta$ has a normal physiological role and targeting $A \beta$ may disrupt these roles over the long term; $\mathbf{7}$. Genetic factors linked to AD can be interpreted independently of amyloid; 8 . APP cleavage and function is more complex than solely the production of $A \beta$, indicating other APP family members may play a role in disease progression; 9 . The triggers of synapse loss, neuronal loss and neuroinflammation in $A D$ are still unclear; 10 . The relationship between $A \beta$ and tau pathologies is unclear; $\mathbf{1 1}$. The onset of dementia in Down's Syndrome is highly variable, despite the presence of fibrillar plaques in 100\% of Down's individuals by the fifth decade; $\mathbf{1 2}$. The APOE4 genotype has numerous functional effects, rather than solely relating to reduced $A \beta$ clearance, including links to enhanced inflammatory phenotypes. Each of these points are discussed in detail in the text.

There are a number of theories in the literature that must be given serious consideration and ultimately integrated into a holistic view of disease. We will elaborate on just some of these, below.

\section{Insulin resistance and Inflammation}

It is suggested that a similar pathogenesis operates in $\mathrm{AD}$ as in Type 2 diabetes (T2D), but restricted to the brain, thus describing AD primarily as a result of cerebral insulin resistance [183]. Certainly cerebral insulin 
resistance is present in AD just as in T2D [184], and the appropriate alterations in post-insulin receptor intracellular signalling have been impressively demonstrated in fresh AD autopsy brains [185]. This idea is likely inseparable from the argument that AD is an inflammatory disease, since evidence that excessive TNF induces insulin resistance is biochemically precise [186] and, as has been reviewed [187], is widespread across many inflammatory diseases, infectious and sterile. Moreover an agent that inhibits TNF production [188] and another that controls insulin resistance [189] have both been shown to reverse AD in experimental models [190].

\section{The inflammatory hypothesis of $A D$ is a valid alternative to the amyloid hypothesis}

We and others have long proposed a role for neuroinflammation, driven by microglia and astrocytes, as a trigger for Alzheimer's pathogenesis [46,125,187,191]. The case for chronic inflammation, as classically defined, rather than $A \beta$, being the primary initiator of $A D$ has a long history, with new evidence continuing to accumulate. From 1989 it has been reported that inflammatory cytokines are essential for the excess APP required for the amyloid hypothesis of AD [192], as well as up-regulating its cleavage to form $A \beta$ [187]. In addition, parallel studies demonstrating that oligomeric $A \beta$ influences synapses through inducing the inflammatory cytokine TNF $[187,193,194]$ have been enlightening. A possible role for neuroinflammation in synapse pathology early in disease has now been acknowledged [195] and there is much evidence, from genetics and measuring indicatory of inflammation very early in $\mathrm{AD}$, that it is in the right place at the right time to be causal, and likely to precede $A \beta$ and tau pathologies [187]. More recently, the clinically approved specific anti-TNF agent, etanercept, is reported to prevent changes caused by administering $A \beta$ to mice intracerebroventricularly [196].

\section{The tau hypothesis of AD}

The concept of hyperphosphorylated tau being a primary mediator of $\mathrm{AD}$, like amyloid, has a long history, which continues to grow [197]. Much interest still exists in where tau sits in the pathogenesis of AD [198]. In our view, $\mathrm{AD}$ is sufficiently diverse that it is conceivable that the role of tau, and where it sits in AD pathology, could vary among individuals. If tau is a primary activator of disease in some cases, it is imperative that the reported harmlessness of phosphorylated tau to neurons during mammalian hibernation [199] be discussed in AD research circles. Furthermore, hyperphosphorylated tau can be considered another histological sign of cytokine activity [187].

\section{Redefining 'neuroinflammation' through viewing the} synapse as a complex multicellular structure is important in future $A D$ research

The inflammatory hypothesis is an example of how amyloid and tau research can be integrated into a novel set of ideas, both expanding the amyloid hypothesis and including it. However, while we use the term 'neuroinflammation' throughout this text and elsewhere, we note that neuroinflammation is poorly defined. In its simplest form neuroinflammation is currently defined by altered glial cell morphology and excess pro-inflammatory cytokine release [46]. This must ultimately give way to a more complex and subtle view of glial function/dysfunction within the multicellular synapse [200].

Stepping back to consider the multitude of factors we have summarised above, a complex picture emerges that consistently points to synaptic dysfunction and loss as a major link between the diverse characteristics of the disease. We have recently pointed out the synapse needs to be re-defined and understood as a multicellular structure where glia play a critical role [46]. This allows us in turn to re-imagine $\mathrm{AD}$.

Microglia and astrocytes are essential to normal synapse biology, including the removal $[201,202]$ and formation of synapses [203,204], and maintenance of synaptic function $[205,206]$. Disruptions in signalling between glia and synapses, which may involve several known cytokines such as TNF, could therefore drive the well-known synapse loss in $\mathrm{AD}$, either independently of, or in conjunction with $A \beta$ [46].

A consequence of this interpretation is that the issue may not be an upregulation of neuroinflammatory signalling from these cells per se, that is involved in disease. Rather, expression of pro-inflammatory cytokines and other neuronal and glial derived molecules regulating the synapse could be disrupted subtly for a host of reasons, well before frank inflammation is apparent. APP, along with presenilin and indeed numerous other factors, may exert effects on the synapse through actions on glial function, leading to either excess synapses (as occurs in autism) or synapse loss (as occurs in AD). This would modify glial function at synapses, and potentially drive synapse loss. Thus, we propose that many of the factors thought to cause inflammation are more likely to cause a dysregulation of glial function at the synapse in the first instance, long before changes in cell morphology become obvious. Consequently, more subtle mechanisms may underpin AD.

Clearly, understanding the physiological roles of microglia and astrocytes at synapses, as opposed to simply considering them as cells with key roles in innate immunity and 'neuroinflammation', is a critical avenue for future research. We suggest future research will reveal that the entire current concept of 'neuroinflammation' is poorly 
understood, defined and characterised. This concept will require profound rethinking before we can truly understand the role of glia in the unperturbed brain and in $\mathrm{AD}$ pathogenesis [46].

\section{Conclusion}

In the words of Joseph Lister (1876)

"In investigating nature you will do well to bear ever in mind that in every question there is the truth, whatever our notions may be. This seems, perhaps, a very simple consideration, yet it is strange how often it seems to be disregarded. I remember at an early period of my own life showing to a man of high reputation as a teacher some matters which I happened to have observed. And I was very much struck and grieved to find that, while all the facts lay equally clear before him, those only which squared with his previous theories seemed to affect his organs of vision."

Lister's quote is salient. Hypotheses are an important part of any scientific method, but the sentiment of Karl Popper, quoted earlier in this article, should be taken seriously. Keeping Popper's views in mind may prevent us from becoming over-reliant upon, and blinkered by, any single hypothesis for $\mathrm{AD}$.

It has been said the amyloid hypothesis, like certain banks, may have become too big to fail [101]. The hypothesis may yet prove its merit, at least in some cases, through early intervention trials with amyloid-directed therapeutics $[70,71]$. However, on the basis of the data discussed here, the role of $A \beta$ as a primary cause of all $A D$ remains debatable. We are therefore concerned by the suggestion that, if anti- $\mathrm{A} \beta$ treatments are successful in patients with EOAD, this would support an argument for treating all AD with anti-A $\beta$ drugs [207]. Such a conclusion would merit questioning without direct clinical evidence that the treatments are effective in LOAD.

We are not arguing that $A \beta$ has no role. In fact it may be a player in a more complex view of disease and, further, its role may even be variable. We suggest instead that to solve the complex riddle of $\mathrm{AD}$, theoretical models must expand beyond $A \beta$ as the central cause of dysfunction, instead including $A \beta$ in a wider theory that accounts for the extensive data and advances in neuroscience that have accumulated over the last decade. Ultimately it is critical that any role for $A \beta$ must be placed in the context of a holistic view of the disease that accounts for all the data.

Even more so, with recent meta-analyses highlighting some major pitfalls with experimental design and statistical power in neuroscience $[208,209]$, we need to be wary. Conclusions drawn from any experiment must be replicated before accepting them as fact, especially considering the difficulty in replicating in vivo studies when using different background animal strains, and different methodological approaches [210,211].

An important suggestion we make is that the concept of neuroinflammation mediated by glia may need to give way to a more subtle understanding of how aberrant glial function at synapses drives AD. We suggest an alternative view that, given evidence for synapse dysfunction as an early event in $\mathrm{AD}$, synapse dysfunction may ipso facto be the cause of AD. We recently suggested [46] a new definition of the synapse as "...a complex, $d y$ namic and often transient structure involving several cells interacting within a sophisticated extracellular matrix and milieu." Within this framework, one of the normal roles of glia in synapse structural plasticity is to modulate and also remove synapses. Improving our understanding of how dysregulation of the multicellular synapse leads to aberrant synapse elimination will likely produce novel insights into mechanisms of synaptic degeneration in $\mathrm{AD}$, and provide insights into the relationship between synaptic degeneration and other pathological hallmarks of the disease. The corollary of this is that if we can identify signaling pathways that reverse glial mechanisms leading to synapse removal, we may identify approaches that could halt or even reverse $\mathrm{AD}$, independent of specific cause. Regardless, if synapse loss is one of the earliest events in disease then we must go back to first principles and understand what drives this loss.

The primary point of our review is to suggest it is inappropriate to ignore equally valid interpretations of data. There are many thousands of papers on Alzheimer's disease, and many of these papers can be interpreted in alternative ways, while still more are contradictory to, and/or inconsistent with, the amyloid hypothesis. There are also many thousands more investigating mechanisms driving synapse function and dysfunction that could be linked to AD literature, given synapse dysfunction is a key early event and accurate correlate of $\mathrm{AD}$ progression. We conclude by suggesting the students, post-docs and young faculty who will determine the course of $\mathrm{AD}$ research in the next decade, must spend time reading this literature extensively, and thinking deeply, and thus become the next generation of leaders that, at the expense of time away from the lab bench, determine the best pathway forward.

\section{Competing interests}

The authors declare that they have no competing interests.

\section{Acknowledgements}

We thank Raphael Zinn for constructive comments on the manuscript and helpful discussions. This work was supported by the Boyarsky family, Stanley and John Roth through the Henry Roth Foundation, the ISG Foundation in memory of Kylie, FiveX in memory of Marko Berger, David King, Doug Battersby, Bill Gruy, Julian Segal, Walter and Edith Sheldon, Tony and Vivian 
Howland-Rose, Amadeus Energy Ltd., Gleneagle Securities, Patricia A. Quick Foundation. The authors wish to thank Nick and Melanie Kell, Joanna Knott and Geoffrey Towner for their support. The funders had no role in the planning, writing, study analysis, decision to publish, or preparation of the manuscript.

\section{Author details}

${ }^{1}$ Garvan Institute of Medical Research, Neuroscience Department, Neurodegenerative Disorders Laboratory, 384 Victoria Street, Darlinghurst, NSW 2010, Australia. ${ }^{2}$ Faculty of Medicine, University of New South Wales, Sydney, Australia. ${ }^{3}$ Research School of Biology, Australian National University, Canberra, Australia.

\section{Received: 28 August 2014 Accepted: 30 August 2014}

Published online: 18 September 2014

\section{References}

1. Glenner GG, Wong CW (1984) Alzheimer's disease: initial report of the purification and characterization of a novel cerebrovascular amyloid protein. Biochem Biophys Res Commun 120:885-890

2. Masters CL (1984) Etiology and pathogenesis of Alzheimer's disease. Pathology 16:233-234

3. Hardy J, Mayer J (2011) The amyloid cascade hypothesis has misled the pharmaceutical industry. Biochem Soc Trans 39:920-923

4. Masters CL, Gajdusek DC, Gibbs CJ Jr (1981) The familial occurrence of Creutzfeldt-Jakob disease and Alzheimer's disease. Brain 104:535-558

5. Prusiner SB, McKinley MP, Bowman KA, Bolton DC, Bendheim PE, Groth DF, Glenner GG (1983) Scrapie prions aggregate to form amyloid-like birefringent rods. Cell 35:349-358

6. Alzheimer A (1907) Ueber eine eigenartige Erkrankung der Hirnrinde. Centralblat fur Nervenheilkunde und Psychiatrie 30:177-179

7. Castellani RJ, Lee HG, Zhu X, Perry G, Smith MA (2008) Alzheimer disease pathology as a host response. J Neuropathol Exp Neurol 67:523-531

8. Allsop D, Landon M, Kidd M (1983) The isolation and amino acid composition of senile plaque core protein. Brain Res 259:348-352

9. Masters $C L$, Simms G, Weinman NA, Multhaup G, McDonald BL, Beyreuther K (1985) Amyloid plaque core protein in Alzheimer disease and Down syndrome. Proc Natl Acad Sci U S A 82:4245-4249

10. Grundke-labal I, Iqbal K, Tung YC, Quinlan M, Wisniewski HM, Binder LI (1986) Abnormal phosphorylation of the microtubule-associated protein tau (tau) in Alzheimer cytoskeletal pathology. Proc Natl Acad Sci U S A 83:4913-4917

11. Yankner BA, Dawes LR, Fisher S, Villa-Komaroff L, Oster-Granite ML, Neve RL (1989) Neurotoxicity of a fragment of the amyloid precursor associated with Alzheimer's disease. Science 245:417-420

12. Kang J, Lemaire HG, Unterbeck A, Salbaum JM, Masters CL, Grzeschik KH, Multhaup G, Beyreuther K, Muller-Hill B (1987) The precursor of Alzheimer's disease amyloid A4 protein resembles a cell-surface receptor. Nature 325:733-736

13. Zigman WB, Devenny DA, Krinsky-McHale SJ, Jenkins EC, Urv TK, Wegiel J, Schupf N, Silverman W (2008) Alzheimer's Disease in Adults with Down Syndrome. Int Rev Res Mental Retardation 36:103-145

14. Levy E, Carman M, Fernandez-Madrid I, Power MD, Lieberburg I, van Duinen SG, Bots GT, Luyendijk W, Frangione B (1990) Mutation of the Alzheimer's disease amyloid gene in hereditary cerebral hemorrhage, Dutch type. Science 248:1124-1126

15. Levy-Lahad E, Wasco W, Poorkaj P, Romano DM, Oshima J, Pettingell WH, Yu CE, Jondro PD, Schmidt SD, Wang K, Crowley AC, Fu YH, Guenette SY, Galas D, Nemens E, Wijsman EM, Bird TD, Schellenberg GD, Tanzi RE (1995) Candidate gene for the chromosome 1 familial Alzheimer's disease locus. Science 269:973-977

16. Sherrington R, Rogaev El, Liang $Y$, Rogaeva EA, Levesque $G$, Ikeda $M, C h i$ Lin C, Li G, Holman K, Tsuda T, Mar L, Foncin JF, Bruni AC, Montesi MP, Sorbi S, Rainero I, Pinessi L, Nee L, Chumakov I, Pollen D, Brookes A Sanseau P, Polinsky RJ, Wasco W, Da Silva HAR, Haines JL, Pericak-Vance MA, Tanzi RE, Roses AD et al (1995) Cloning of a gene bearing missense mutations in early-onset familial Alzheimer's disease. Nature 375:754-760

17. Dimitrov M, Alattia J-R, Lemmin $T$, Lehal R, Fligier A, Houacine J, Hussain I, Radtke F, Dal Peraro M, Beher D, Fraering PC (2013) Alzheimer's disease mutations in APP but not $\gamma$-secretase modulators affect epsilon-cleavage-dependent AICD production. Nat Commun 4:2246
18. Games D, Adams D, Alessandrini R, Barbour R, Borthelette P, Blackwell C, Carr T, Clemens J, Donaldson T, Gillespie F, Guido T, Hagopian S, Johnson-Wood K, Khan K, Lee M, Leibowitz P, Lieberburg I, Little S, Masliah E, Mcconlogue L, Montoya-Zavala M, Mucke L, Paganini L, Penniman E, Power M, Schenk D, Seubert P, Snyder B, Soriano F, Tan H et al (1995) Alzheimer-type neuropathology in transgenic mice overexpressing V717F beta-amyloid precursor protein. Nature 373:523-527

19. Pike CJ, Burdick D, Walencewicz AJ, Glabe CG, Cotman CW (1993) Neurodegeneration induced by $\beta$-amyloid peptides in vitro: The role of peptide assembly state. J Neurosci 13:1676-1687

20. Ittner LM, Gotz J (2011) Amyloid-beta and tau-a toxic pas de deux in Alzheimer's disease. Nat Rev Neurosci 12:65-72

21. Thies W, Bleiler $L$ (2011) 2011 Alzheimer's disease facts and figures. Alzheimer's and Dementia 7:208-244

22. Corder EH, Saunders AM, Strittmatter WJ, Schmechel DE, Gaskell PC, Small GW, Roses AD, Haines JL, Pericak-Vance MA (1993) Gene dose of apolipoprotein E type 4 allele and the risk of Alzheimer's disease in late onset families. Science 261:921-923

23. Jonsson T, Atwal JK, Steinberg S, Snaedal J, Jonsson PV, Bjornsson S, Stefansson H, Sulem P, Gudbjartsson D, Maloney J, Hoyte K, Gustafson A, Liu Y, Lu Y, Bhangale T, Graham RR, Huttenlocher J, Bjornsdottir G, Andreassen OA, Jonsson EG, Palotie A, Behrens TW, Magnusson OT, Kong A, Thorsteinsdottir U, Watts RJ, Stefansson K (2012) A mutation in APP protects against Alzheimer/'s disease and age-related cognitive decline. Nature 488:96-99

24. Uylings HBM, de Brabander JM (2002) Neuronal Changes in Normal Human Aging and Alzheimer's Disease. Brain Cogn 49:268-276

25. Conforti L, Adalbert R, Coleman MP (2007) Neuronal death: where does the end begin? Trends Neurosci 30:159-166

26. William CM, Andermann ML, Goldey GJ, Roumis DK, Reid RC, Shatz CJ, Albers MW, Frosch MP, Hyman BT (2012) Synaptic plasticity defect following visual deprivation in Alzheimer's disease model transgenic mice. J Neurosci 32:8004-8011

27. Masliah E, Mallory M, Alford M, De Teresa R, Hansen LA, McKeel DW Jr, Morris JC (2001) Altered expression of synaptic proteins occurs early during progression of Alzheimer's disease. Neurology 56:127-129

28. Terry RD, Masliah E, Salmon DP, Butters N, DeTeresa R, Hill R, Hansen LA Katzman R (1991) Physical basis of cognitive alterations in alzheimer's disease: Synapse loss is the major correlate of cognitive impairment. Ann Neurol 30:572-580

29. Davies CA, Mann DM, Sumpter PQ, Yates PO (1987) A quantitative morphometric analysis of the neuronal and synaptic content of the frontal and temporal cortex in patients with Alzheimer's disease. J Neurol Sci 78:151-164

30. Mesulam MM (2000) A Plasticity-Based Theory of the Pathogenesis of Alzheimer's Disease. Ann N Y Acad Sci 924:42-52

31. Selkoe DJ (2002) Alzheimer's disease is a synaptic failure. Science 298:789-791

32. Bittner T, Burgold S, Dorostkar MM, Fuhrmann M, Wegenast-Braun BM, Schmidt B, Kretzschmar H, Herms J (2012) Amyloid plaque formation precedes dendritic spine loss. Acta Neuropathol 124:797-807

33. Lacor PN, Buniel MC, Furlow PW, Clemente AS, Velasco PT, Wood M, Viola KL, Klein WL (2007) Aß Oligomer-Induced Aberrations in Synapse Composition, Shape, and Density Provide a Molecular Basis for Loss of Connectivity in Alzheimer's Disease. J Neurosci 27:796-807

34. Calabrese B, Shaked GM, Tabarean IV, Braga J, Koo EH, Halpain S (2007) Rapid, concurrent alterations in pre- and postsynaptic structure induced by naturally-secreted amyloid-beta protein. Mol Cell Neurosci 35:183-193

35. Evans NA, Facci L, Owen DE, Soden PE, Burbidge SA, Prinjha RK, Richardson JC, Skaper SD (2008) Abeta(1-42) reduces synapse number and inhibits neurite outgrowth in primary cortical and hippocampal neurons: a quantitative analysis. J Neurosci Methods 175:96-103

36. Shankar GM, Bloodgood BL, Townsend M, Walsh DM, Selkoe DJ, Sabatini BL (2007) Natural oligomers of the Alzheimer amyloid-beta protein induce reversible synapse loss by modulating an NMDA-type glutamate receptor-dependent signaling pathway. J Neurosci 27:2866-2875

37. Shrestha BR, Vitolo OV, Joshi P, Lordkipanidze T, Shelanski M, Dunaevsky A (2006) Amyloid beta peptide adversely affects spine number and motility in hippocampal neurons. Mol Cell Neurosci 33:274-282

38. Wei W, Nguyen LN, Kessels HW, Hagiwara H, Sisodia S, Malinow R (2010) Amyloid beta from axons and dendrites reduces local spine number and plasticity. Nat Neurosci 13:190-196 
39. Westmark CJ (2012) What's hAPPening at synapses? The role of amyloid beta-protein precursor and beta-amyloid in neurological disorders. Mol Psychiatry 18:425-434

40. Shankar GM, Li S, Mehta TH, Garcia-Munoz A, Shepardson NE, Smith I, Brett FM, Farrell MA, Rowan MJ, Lemere CA, Regan CM, Walsh DM, Sabatini BL, Selkoe DJ (2008) Amyloid-beta protein dimers isolated directly from Alzheimer's brains impair synaptic plasticity and memory. Nat Med 14:837-842

41. Brouillette J, Caillierez R, Zommer N, Alves-Pires C, Benilova I, Blum D, De Strooper B, Buée L (2012) Neurotoxicity and Memory Deficits Induced by Soluble Low-Molecular-Weight Amyloid- $\beta 1-42$ Oligomers Are Revealed In Vivo by Using a Novel Animal Model. J Neurosci 32:7852-7861

42. Lanz TA, Carter DB, Merchant KM (2003) Dendritic spine loss in the hippocampus of young PDAPP and Tg2576 mice and its prevention by the ApoE2 genotype. Neurobiol Dis 13:246-253

43. Boncristiano S, Calhoun ME, Howard V, Bondolfi L, Kaeser SA, Wiederhold KH, Staufenbiel M, Jucker M (2005) Neocortical synaptic bouton number is maintained despite robust amyloid deposition in APP23 transgenic mice. Neurobiol Aging 26:607-613

44. Spires TL, Meyer-Luehmann M, Stern EA, McLean PJ, Skoch J, Nguyen PT, Bacskai BJ, Hyman BT (2005) Dendritic spine abnormalities in amyloid precursor protein transgenic mice demonstrated by gene transfer and intravital multiphoton microscopy. J Neurosci 25:7278-7287

45. Counts SE, Alldred MJ, Che S, Ginsberg SD, Mufson EJ (2014) Synaptic gene dysregulation within hippocampal CA1 pyramidal neurons in mild cognitive impairment. Neuropharmacology 79:172-179

46. Morris GP, Clark IA, Zinn R, Vissel B (2013) Microglia: A new frontier for synaptic plasticity, learning and memory, and neurodegenerative disease research. Neurobiol Learn Mem 105:40-53

47. Schenk D, Barbour R, Dunn W, Gordon G, Grajeda H, Guido T, Hu K, Huang J, Johnson-Wood K, Khan K, Kholodenko D, Lee M, Liao Z, Lieberburg I, Motter R, Mutter L, Soriano F, Shopp G, Vasquez N, Vandevert C, Walker S, Wogulis M, Yednock T, Games D, Seubert P (1999) Immunization with amyloid-[beta] attenuates Alzheimer-disease-like pathology in the PDAPP mouse. Nature 400:173-177

48. Lobello K, Ryan JM, Liu E, Rippon G, Black R (2012) Targeting Beta Amyloid: A Clinical Review of Immunotherapeutic Approaches in Alzheimer's Disease. Int J Alzheimers Dis 2012:628070

49. Boche D, Donald J, Love S, Harris S, Neal JW, Holmes C, Nicoll JA (2010) Reduction of aggregated Tau in neuronal processes but not in the cell bodies after Abeta42 immunisation in Alzheimer's disease. Acta Neuropathol 120:13-20

50. Nicoll JA, Wilkinson D, Holmes C, Steart P, Markham H, Weller RO (2003) Neuropathology of human Alzheimer disease after immunization with amyloid-beta peptide: a case report. Nat Med 9:448-452

51. Winblad B, Andreasen N, Minthon L, Floesser A, Imbert G, Dumortier T, Maguire RP, Blennow K, Lundmark J, Staufenbiel M, Orgogozo JM, Graf A (2012) Safety, tolerability, and antibody response of active Abeta immunotherapy with CAD106 in patients with Alzheimer's disease: randomised, double-blind, placebo-controlled, first-in-human study. Lancet Neurol 11:597-604

52. Arai H, Suzuki H, Yoshiyama T, Lobello K, Peng Y, Liu E, Ketter N, Margolin R, Jackson N, Fujimoto Y (2013) Safety, tolerability and immunogenicity of an immunotherapeutic vaccine (vanutide cridificar [ACC-001]) and the QS-21 adjuvant in Japanese individuals with mild-to-moderate Alzheimer's disease: A phase lla, multicenter, randomized, adjuvant and placebo clinical trial. Alzheimers Dement 9:P282

53. ClinicalTrials.gov (2013) Clinical- and Immunological Activity, Safety and Tolerability of Different Doses / Formulations of AFFITOPE AD02 in Early Alzheimer's Disease., http://clinicaltrials.gov/show/NCT01117818. Accessed 11 August 2014

54. Doody RS, Thomas RG, Farlow M, Iwatsubo T, Vellas B, Joffe S, Kieburtz K, Raman R, Sun X, Aisen PS, Siemers E, Liu-Seifert H, Mohs R (2014) Phase 3 Trials of Solanezumab for Mild-to-Moderate Alzheimer's Disease. N Engl J Med 370:311-321

55. Salloway S, Sperling R, Fox NC, Blennow K, Klunk W, Raskind M, Sabbagh M, Honig LS, Porsteinsson AP, Ferris S, Reichert M, Ketter N, Nejadnik B, Guenzler V, Miloslavsky M, Wang D, Lu Y, Lull J, Tudor IC, Liu E, Grundman M, Yuen E, Black R, Brashear HR (2014) Two Phase 3 Trials of Bapineuzumab in Mild-to-Moderate Alzheimer's disease. N Engl J Med 370:322-333
56. Ostrowitzki S, Deptula D, Thurfjell L, Barkhof F, Bohrmann B, Brooks DJ, Klunk WE, Ashford E, Yoo K, Xu ZX, Loetscher H, Santarelli L (2012) Mechanism of amyloid removal in patients with Alzheimer disease treated with gantenerumab. Arch Neurol 69:198-207 D

57. Roche IU (2014) Roche announces phase II clinical results of crenezumab in Alzheimer's disease., http://www.roche.com/investors/ir_update/inv-update2014-07-16.htm. Accessed June 282014

58. La Porte SL, Bollini SS, Lanz TA, Abdiche YN, Rusnak AS, Ho WH, Kobayashi D, Harrabi O, Pappas D, Mina EW, Milici AJ, Kawabe TT, Bales K, Lin JC, Pons J (2012) Structural basis of C-terminal beta-amyloid peptide binding by the antibody ponezumab for the treatment of Alzheimer's disease. J Mol Biol 421:525-536

59. Coric V, van Dyck CH, Salloway S, Andreasen N, Brody M, Richter RW, Soininen $\mathrm{H}$, Thein S, Shiovitz T, Pilcher G, Colby S, Rollin L, Dockens R, Pachai C, Portelius E, Andreasson U, Blennow K, Soares H, Albright C, Feldman HH, Berman RM (2012) Safety and tolerability of the gamma-secretase inhibitor avagacestat in a phase 2 study of mild to moderate Alzheimer disease. Arch Neurol 69:1430-1440

60. Doody RS, Raman R, Farlow M, Iwatsubo T, Vellas B, Joffe S, leburtz K, He F, Sun X, Thomas RG, Aisen PS, Siemers E, Sethuraman G, Mohs R, Alzheimer's Disease Cooperative Study Steering Committee, Semagacestat Study Group (2013) A phase 3 trial of semagacestat for treatment of Alzheimer's disease. N Engl J Med 369:341-350

61. Ross J, Sharma S, Winston J, Nunez M, Bottini G, Franceschi M, Scarpini E, Frigerio E, Fiorentini F, Fernandez M, Sivilia S, Giardino L, Calza L, Norris D, Cicirello H, Casula D, Imbimbo BP (2013) CHF5074 reduces biomarkers of neuroinflammation in patients with mild cognitive impairment: a 12-week, double-blind, placebo-controlled study. Curr Alzheimer Res 10:742-753

62. Rogers K, Felsenstein KM, Hrdlicka L, Tu Z, Albayya F, Lee W, Hopp S, Miller MJ, Spaulding D, Yang Z, Hodgdon H, Nolan S, Wen M, Costa D, Blain JF, Freeman E, De Strooper B, Vulsteke V, Scrocchi L, Zetterberg H, Portelius E, Hutter-Paier B, Havas D, Ahlijanian M, Flood D, Leventhal L, Shapiro G, Patzke H, Chesworth R, Koenig G (2012) Modulation of gamma-secretase by EVP-0015962 reduces amyloid deposition and behavioral deficits in Tg2576 mice. Mol Neurodegener 7:61

63. Green RC, Schneider LS, Amato DA, Beelen AP, Wilcock G, Swabb EA, Zavitz KH, Tarenflurbil Phase 3 Study Group (2009) Effect of tarenflurbil on cognitive decline and activities of daily living in patients with mild Alzheimer disease: a randomized controlled trial. JAMA 302:2557-2564

64. Forman M, Palcza J, Tseng J, Leempoels J, Ramael S, Han D, Jhee S, Ereshefsky L, Tanen M, Laterza O, Dockendorf M, Krishna G, Ma L, Wagner J, Troyer M (2012) The novel BACE inhibitor MK-8931 dramatically lowers cerebrospinal fluid $A \beta$ peptides in healthy subjects following single- and multiple-dose administration. Alzheimers Dement 8:P704

65. Ghosh AK, Brindisi M, Tang J (2012) Developing beta-secretase inhibitors for treatment of Alzheimer's disease. J Neurochem 120(Suppl 1):71-83

66. LaFerla FM, Green KN (2012) Animal Models of Alzheimer Disease. Cold Spring Harbor Perspect Med 1:2(11)

67. Mullane K, Williams M (2013) Alzheimer's therapeutics: Continued clinical failures question the validity of the amyloid hypothesis-but what lies beyond? Biochem Pharmacol 85:289-305

68. Selkoe DJ (2011) Resolving controversies on the path to Alzheimer's therapeutics. Nat Med 17:1060-1065

69. Oddo S, Billings L, Kesslak JP, Cribbs DH, LaFerla FM (2004) A Immunotherapy Leads to Clearance of Early, but Not Late, Hyperphosphorylated Tau Aggregates via the Proteasome. Neuron 43:321-332

70. Morris JC, Aisen PS, Bateman RJ, Benzinger TL, Cairns NJ, Fagan AM, Ghetti B, Goate AM, Holtzman DM, Klunk WE, McDade E, Marcus DS, Martins RN, Masters CL, Mayeux R, Oliver A, Quaid K, Ringman JM, Rossor MN, Salloway S, Schofield PR, Selsor NJ, Sperling RA, Weiner MW, Xiong C, Moulder KL, Buckles VD (2012) Developing an international network for Alzheimer research: The Dominantly Inherited Alzheimer Network. Clinical Invest 2:975-984

71. Reiman EM, Langbaum JB, Fleisher AS, Caselli RJ, Chen K, Ayutyanont N, Quiroz YT, Kosik KS, Lopera F, Tariot PN (2011) Alzheimer's Prevention Initiative: a plan to accelerate the evaluation of presymptomatic treatments. J Alzheimers Dis 26(Suppl 3):321-329

72. Sperling RA, Rentz DM, Johnson KA, Karlawish J, Donohue M, Salmon DP, Aisen P (2014) The A4 Study: Stopping AD Before Symptoms Begin? Sci Transl Med 6:228fs213 
73. Watt AD, Crespi GA, Down RA, Ascher DB, Gunn A, Perez KA, McLean CA, Villemagne VL, Parker MW, Barnham KJ, Miles LA (2014) Do current therapeutic anti-Abeta antibodies for Alzheimer's disease engage the target? Acta Neuropathol 127:803-810

74. Martins IC, Kuperstein I, Wilkinson H, Maes E, Vanbrabant M, Jonckheere W, Van Gelder P, Hartmann D, D'Hooge R, De Strooper B, Schymkowitz J, Rousseau F (2008) Lipids revert inert Abeta amyloid fibrils to neurotoxic protofibrils that affect learning in mice. EMBO J 27:224-233

75. Zakaib GW (2014) Anti-Amyloid Therapies Combine Forces to Knock Out Plaques., http://www.alzforum.org/news/conference-coverage/anti-amyloid-therapiescombine-forces-knock-out-plaques. Accessed 01.08.2014

76. Smith MA, Atwood CS, Joseph JA, Perry G (2002) Predicting the failure of amyloid-beta vaccine. Lancet 359:1864-1865

77. Price JL, McKeel DW Jr, Buckles VD, Roe CM, Xiong C, Grundman M, Hansen LA, Petersen RC, Parisi JE, Dickson DW, Smith CD, Davis DG, Schmitt FA, Markesbery WR, Kaye J, Kurlan R, Hulette C, Kurland BF, Higdon R, Kukull W, Morris JC (2009) Neuropathology of nondemented aging: Presumptive evidence for preclinical Alzheimer disease. Neurobiol Aging 30:1026-1036

78. Fagan AM, Mintun MA, Shah AR, Aldea P, Roe CM, Mach RH, Marcus D, Morris JC, Holtzman DM (2009) Cerebrospinal fluid tau and ptau(181) increase with cortical amyloid deposition in cognitively normal individuals: implications for future clinical trials of Alzheimer's disease. EMBO Mol Med 1:371-380

79. Davis DG, Schmitt FA, Wekstein DR, Markesbery WR (1999) Alzheimer neuropathologic alterations in aged cognitively normal subjects. J Neuropathol Exp Neurol 58:376-388

80. Chételat G, La Joie R, Villain N, Perrotin A, de La Sayette V, Eustache F, Vandenberghe R (2013) Amyloid imaging in cognitively normal individuals, at-risk populations and preclinical Alzheimer's disease. Neurol Clin 2:356-365

81. Perls T (2004) Dementia-free centenarians. Exp Gerontol 39:1587-1593

82. Poon LW, Woodard JL, Stephen Miller L, Stephen Miller L, Green R, Gearing M, Davey A, Arnold J, Martin P, Siegler IC, Nahapetyan L, Kim YS, Markesbery W (2012) Understanding dementia prevalence among centenarians. J Gerontol A Biol Sci Med Sci 67:358-365

83. Snitz BE, Weissfeld LA, Lopez OL, Kuller LH, Saxton J, Singhabahu DM, Klunk WE, Mathis CA, Price JC, Ives DG, Cohen AD, McDade E, Dekosky ST (2013) Cognitive trajectories associated with beta-amyloid deposition in the oldest-old without dementia. Neurology 80:1378-1384

84. Morris JC, Roe CM, Grant EA, Head D, Storandt M, Goate AM, Fagan AM, Holtzman DM, Mintun MA (2009) Pittsburgh compound B imaging and prediction of progression from cognitive normality to symptomatic Alzheimer disease. Arch Neurol 66:1469-1475

85. Rentz DM, Locascio JJ, Becker JA, Moran EK, Eng E, Buckner RL, Sperling RA Johnson KA (2010) Cognition, reserve, and amyloid deposition in normal aging. Ann Neurol 67:353-364

86. Engler $H$, Forsberg A, Almkvist O, Blomquist $G$, Larsson E, Savitcheva I, Wall A, Ringheim A, Långström B, Nordberg A (2006) Two-year follow-up of amyloid deposition in patients with Alzheimer's disease. Brain 129:2856-2866

87. Ingelsson M, Fukumoto $\mathrm{H}$, Newell $\mathrm{KL}$, Growdon JH, Hedley-Whyte ET, Frosch MP, Albert MS, Hyman BT, Irizarry MC (2004) Early Abeta accumulation and progressive synaptic loss, gliosis, and tangle formation in AD brain. Neurology 62:925-931

88. Chetelat G (2013) Alzheimer disease: A[beta]-independent processes-rethinking preclinical AD. Nat Rev Neurol 9:123-124

89. Tsai J, Grutzendler J, Duff K, Gan WB (2004) Fibrillar amyloid deposition leads to local synaptic abnormalities and breakage of neuronal branches. Nat Neurosci 7:1181-1183

90. Dickson TC, Vickers JC (2001) The morphological phenotype of betaamyloid plaques and associated neuritic changes in Alzheimer's disease. Neuroscience 105:99-107

91. Reiman EM, Chen K, Liu X, Bandy D, Yu M, Lee W, Ayutyanont N, Keppler J, Reeder SA, Langbaum JB, Alexander GE, Klunk WE, Mathis CA, Price JC, Aizenstein HJ, DeKosky ST, Caselli RJ (2009) Fibrillar amyloid-beta burden in cognitively normal people at 3 levels of genetic risk for Alzheimer's disease. Proc Natl Acad Sci U S A 106:6820-6825

92. Hedden $\mathrm{T}$, Oh H, Younger AP, Patel TA (2013) Meta-analysis of amyloid-cognition relations in cognitively normal older adults. Neurology 80:1341-1348

93. Savory J, Ghribi O, Herman MM (2002) Is amyloid $\beta$-peptide neurotoxic or neuroprotective and what is its role in the binding of metal ions? Neurobiol Aging 23:1089-1092
94. Stern Y (2012) Cognitive reserve in ageing and Alzheimer's disease. Lancet Neurol 11:1006-1012

95. Atwood CS, Bowen RL, Smith MA, Perry G (2003) Cerebrovascular requirement for sealant, anti-coagulant and remodeling molecules that allow for the maintenance of vascular integrity and blood supply. Brain Res Rev 43:164-178

96. Weller RO, Subash M, Preston SD, Mazanti I, Carare RO (2008) Perivascular drainage of amyloid-beta peptides from the brain and its failure in cerebral amyloid angiopathy and Alzheimer's disease. Brain Pathol 18:253-266

97. Yasojima K, Akiyama H, McGeer EG, McGeer PL (2001) Reduced neprilysin in high plaque areas of Alzheimer brain: a possible relationship to deficient degradation of beta-amyloid peptide. Neurosci Lett 297:97-100

98. Cook DG, Leverenz JB, McMillan PJ, Kulstad JJ, Ericksen S, Roth RA, Schellenberg GD, Jin LW, Kovacina KS, Craft S (2003) Reduced hippocampal insulin-degrading enzyme in late-onset Alzheimer's disease is associated with the apolipoprotein E-epsilon4 allele. Am J Pathol 162:313-319

99. Deane R, Sagare A, Hamm K, Parisi M, Lane S, Finn MB, Holtzman DM, Zlokovic BV (2008) apoE isoform-specific disruption of amyloid beta peptide clearance from mouse brain. J Clin Invest 118:4002-4013

100. Ferreira ST, Klein WL (2011) The A oligomer hypothesis for synapse failure and memory loss in Alzheimer's disease. Neurobiol Learn Mem 96:529-543

101. Castellani RJ, Smith MA (2011) Compounding artefacts with uncertainty, and an amyloid cascade hypothesis that is 'too big to fail'. J Pathol 224:147-152

102. DaRocha-Souto B, Scotton TC, Coma M, Serrano-Pozo A, Hashimoto T, Sereno L, Rodriguez M, Sanchez B, Hyman BT, Gomez-Isla T (2011) Brain oligomeric beta-amyloid but not total amyloid plaque burden correlates with neuronal loss and astrocyte inflammatory response in amyloid precursor protein/tau transgenic mice. J Neuropathol Exp Neurol 70:360-376

103. McDonald JM, Savva GM, Brayne C, Welzel AT, Forster G, Shankar GM, Selkoe DJ, Ince PG, Walsh DM (2010) The presence of sodium dodecyl sulphate-stable $A \beta$ dimers is strongly associated with Alzheimer-type dementia. Brain 133:1328-1341

104. Benilova I, Karran E, De Strooper B (2012) The toxic Abeta oligomer and Alzheimer's disease: an emperor in need of clothes. Nat Neurosci 15:349-357

105. Larson ME, Lesne SE (2012) Soluble Abeta oligomer production and toxicity. J Neurochem 120(Suppl 1):125-139

106. Esparza TJ, Zhao H, Cirrito JR, Cairns NJ, Bateman RJ, Holtzman DM, Brody DL (2013) Amyloid-beta oligomerization in Alzheimer dementia versus high-pathology controls. Ann Neurol 73:104-119

107. Watt AD, Perez KA, Rembach A, Sherrat NA, Hung LW, Johanssen T, McLean CA, Kok WM, Hutton CA, Fodero-Tavoletti M, Masters CL, Villemagne VL, Barnham KJ (2013) Oligomers, fact or artefact? SDS-PAGE induces dimerization of beta-amyloid in human brain samples. Acta Neuropathol 125:549-564

108. Atwood CS, Martins RN, Smith MA, Perry G (2002) Senile plaque composition and posttranslational modification of amyloid- $\beta$ peptide and associated proteins. Peptides 23:1343-1350

109. Kudinova NV, Kudinov AR, Berezov TT (2007) Amyloid beta: functional protein or biological junk? Biomeditsinskaia khimiia 53:119-127

110. Pimplikar SW (2009) Reassessing the amyloid cascade hypothesis of Alzheimer's disease. Int J Biochem Cell Biol 41:1261-1268

111. Gilbert BJ (2013) The role of amyloid beta in the pathogenesis of Alzheimer's disease. J Clin Pathol 66:362-366

112. Farrer LA, Myers RH, Cupples LA, St George-Hyslop PH, Bird TD, Rossor MN, Mullan MJ, Polinsky R, Nee L, Heston L (1990) Transmission and age-at-onset patterns in familial Alzheimer's disease: evidence for heterogeneity. Neurology 40:395-403

113. Komarova NL, Thalhauser CJ (2011) High degree of heterogeneity in Alzheimer's disease progression patterns. PLoS Comput Biol 7:e1002251

114. Stopford CL, Snowden JS, Thompson JC, Neary D (2008) Variability in cognitive presentation of Alzheimer's disease. Cortex 44:185-195

115. Shepherd C, McCann H, Halliday GM (2009) Variations in the neuropathology of familial Alzheimer's disease. Acta Neuropathol 118:37-52

116. Koedam EL, Lauffer $V$, van der Vlies AE, van der Flier WM, Scheltens $P$, Pijnenburg YA (2010) Early-versus late-onset Alzheimer's disease: more than age alone. J Alzheimers Dis 19:1401-1408

117. Mastroeni D, Grover A, Delvaux E, Whiteside C, Coleman PD, Rogers J (2011) Epigenetic mechanisms in Alzheimer's disease. Neurobiol Aging $32: 1161-1180$ 
118. Whitehouse PJ, George DR (2011) Uncertain progress on the fuzzy boundaries of Alzheimer's disease: reading between the guidelines. J Alzheimers Dis 26:1-5

119. Villemagne VL, Ataka S, Mizuno T, Brooks WS, Wada Y, Kondo M, Jones G, Watanabe Y, Mulligan R, Nakagawa M, Miki T, Shimada H, O'Keefe GJ, Masters CL, Mori H, Rowe CC (2009) High striatal amyloid beta-peptide deposition across different autosomal Alzheimer disease mutation types. Arch Neurol 66:1537-1544

120. Thal DR, Rub U, Orantes M, Braak H (2002) Phases of A beta-deposition in the human brain and its relevance for the development of AD. Neurology 58:1791-1800

121. Resende R, Marques SC, Ferreiro E, Simoes I, Oliveira CR, Pereira CM (2013) Effect of alpha-synuclein on amyloid beta-induced toxicity: relevance to Lewy body variant of Alzheimer disease. Neurochem Res 38:797-806

122. Robakis NK (2011) Mechanisms of AD neurodegeneration may be independent of Abeta and its derivatives. Neurobiol Aging 32:372-379

123. Perry G, Castellani RJ, Moreira PI, Lee HG, Zhu X, Smith MA (2008) Pathology's new role: defining disease process and protective responses. Int J Clin Exp Pathol 1:1-4

124. Bryan KJ, Lee H, Perry G, Smith MA, Casadesus G (2009) Transgenic Mouse Models of Alzheimer's Disease: Behavioral Testing and Considerations. In: Buccafusco JJ (ed) Methods of Behavior Analysis in Neuroscience, 2nd edn. CRC Press, Boca Raton (FL)

125. Wright AL, Zinn R, Hohensinn B, Konen LM, Beynon SB, Tan RP, Clark IA Abdipranoto A, Vissel B (2013) Neuroinflammation and Neuronal Loss Precede Abeta Plaque Deposition in the hAPP-J20 Mouse Model of Alzheimer's Disease. PLoS One 8:e59586

126. D'Hooge R, Nagels G, Westland CE, Mucke L, De Deyn PP (1996) Spatial learning deficit in mice expressing human 751-amino acid beta-amyloid precursor protein. Neuroreport 7:2807-2811

127. Yamaguchi F, Richards SJ, Beyreuther K, Salbaum M, Carlson GA, Dunnett SB (1991) Transgenic mice for the amyloid precursor protein 695 isoform have impaired spatial memory. Neuroreport 2:781-784

128. Rovelet-Lecrux A, Hannequin D, Raux G, Le Meur N, Laquerriere A, Vital A, Dumanchin C, Feuillette S, Brice A, Vercelletto M, Dubas F, Frebourg T, Campion D (2006) APP locus duplication causes autosomal dominant early-onset Alzheimer disease with cerebral amyloid angiopathy. Nat Genet 38:24-26

129. Blom ES, Viswanathan J, Kilander L, Helisalmi S, Soininen H, Lannfelt L, Ingelsson M, Glaser A, Hiltunen M (2008) Low prevalence of APP duplications in Swedish and Finnish patients with early-onset Alzheimer's disease. Eur J Hum Genet 16:171-175

130. Sleegers K, Brouwers N, Gijselinck I, Theuns J, Goossens D, Wauters J, Del-Favero J, Cruts M, van Duijn CM, Van Broeckhoven C (2006) APP duplication is sufficient to cause early onset Alzheimer's dementia with cerebral amyloid angiopathy. Brain 129:2977-2983

131. Westerman MA, Cooper-Blacketer D, Mariash A, Kotilinek L, Kawarabayashi T, Younkin LH, Carlson GA, Younkin SG, Ashe KH (2002) The Relationship between A $\beta$ and Memory in the Tg2576 Mouse Model of Alzheimer's Disease. J Neurosci 22:1858-1867

132. Lee KW, Lee SH, Kim H, Song JS, Yang SD, Paik SG, Han PL (2004) Progressive cognitive impairment and anxiety induction in the absence of plaque deposition in C57BL/6 inbred mice expressing transgenic amyloid precursor protein. J Neurosci Res 76:572-580

133. Savonenko AV, Xu GM, Price DL, Borchelt DR, Markowska AL (2003) Normal cognitive behavior in two distinct congenic lines of transgenic mice hyperexpressing mutant APP SWE. Neurobiol Dis 12:194-211

134. Ruiz-Opazo N, Kosik KS, Lopez LV, Bagamasbad P, Ponce LR, Herrera VL (2004) Attenuated hippocampus-dependent learning and memory decline in transgenic TgAPPswe Fischer-344 rats. Mol Med 10:36-44

135. Kalback W, Watson MD, Kokjohn TA, Kuo Y-M, Weiss N, Luehrs DC, Lopez J, Brune D, Sisodia SS, Staufenbiel M, Emmerling M, Roher AE (2001) APP Transgenic Mice Tg2576 Accumulate A $\beta$ Peptides That Are Distinct from the Chemically Modified and Insoluble Peptides Deposited in Alzheimer's Disease Senile Plaquest. Biochemistry 41:922-928

136. Kuo Y-M, Kokjohn TA, Beach TG, Sue LI, Brune D, Lopez JC, Kalback WM, Abramowski D, Sturchler-Pierrat C, Staufenbiel M, Roher AE (2001) Comparative Analysis of Amyloid- $\beta$ Chemical Structure and Amyloid Plaque Morphology of Transgenic Mouse and Alzheimer's Disease Brains. J Biol Chem 276:12991-12998
137. Ryman D, Lamb BT (2006) Genetic and environmental modifiers of Alzheimer's disease phenotypes in the mouse. Curr Alzheimer Res 3:465-473

138. Dolgin E (2013) Old mice require new experimental tricks to study aging process. Nat Med 19:518-519

139. Puzzo D, Arancio O (2013) Amyloid-beta peptide: Dr. Jekyll or Mr. Hyde? J Alzheimers Dis 33(Suppl 1):S111-S120

140. Delerue F, Sjollema G, Whittle B, Kruger S, Andrews D, Gotz J (2013) Single Nucleotide Variants (SNVs) Define Senescence-Accelerated SAMP8 Mice, a Model of a Geriatric Condition. J Alzheimers Dis 36:349-363

141. Capsoni S, Ugolini G, Comparini A, Ruberti F, Berardi N, Cattaneo A (2000) Alzheimer-like neurodegeneration in aged antinerve growth factor transgenic mice. Proc Natl Acad Sci U S A 97:6826-6831

142. Yamasaki TR, Blurton-Jones M, Morrissette DA, Kitazawa M, Oddo S, LaFerla FM (2007) Neural Stem Cells Improve Memory in an Inducible Mouse Model of Neuronal Loss. J Neurosci 27:11925-11933

143. Krstic D, Madhusudan A, Doehner J, Vogel P, Notter T, Imhof C, Manalastas A, Hilfiker M, Pfister S, Schwerdel C, Riether C, Meyer U, Knuesel I (2012) Systemic immune challenges trigger and drive Alzheimer-like neuropathology in mice. J Neuroinflammation 9:151

144. Saito T, Matsuba Y, Mihira N, Takano J, Nilsson P, Itohara S, Iwata N, Saido TC (2014) Single App knock-in mouse models of Alzheimer's disease. Nat Neurosci 17:661-663

145. Tanzi RE (2012) The Genetics of Alzheimer Disease. Cold Spring Harbor Perspect Med 1:2(10)

146. Carvalho C, Machado N, Mota PC, Correia SC, Cardoso S, Santos RX, Santos MS, Oliveira CR, Moreira PI (2013) Type 2 diabetic and Alzheimer's disease mice present similar behavioral, cognitive, and vascular anomalies. J Alzheimers Dis 35:623-635

147. Hong $X, B u$ L, Wang Y, Xu J, Wu J, Huang Y, Liu J, Suo H, Yang L, Shi Y, Lou $Y$, Sun Z, Zhu G, Behnisch T, Yu M, Jia J, Hai W, Meng H, Liang S, Huang F, Zou Y, Ge J (2013) Increases in the risk of cognitive impairment and alterations of cerebral beta-amyloid metabolism in mouse model of heart failure. PLoS One 8:e63829

148. Lambert JC, Ibrahim-Verbaas CA, Harold D, Naj AC, Sims R, Bellenguez C, Jun G, Destefano AL, Bis JC, Beecham GW, Grenier-Boley B, Russo G, Thornton-Wells TA, Jones N, Smith AV, Chouraki V, Thomas C, Ikram MA, Zelenika D, Vardarajan BN, Kamatani Y, Lin CF, Gerrish A, Schmidt H, Kunkle B, Dunstan ML, Ruiz A, Bihoreau MT, Choi SH, Reitz C et al (2013) Meta-analysis of 74,046 individuals identifies 11 new susceptibility loci for Alzheimer's disease. Nat Genet 45:1452-1458

149. Tanzi RE, Bertram L (2005) Twenty Years of the Alzheimer's Disease Amyloid Hypothesis: A Genetic Perspective. Cell 120:545-555

150. Podtelezhnikov AA, Tanis KQ, Nebozhyn M, Ray WJ, Stone DJ, Loboda AP (2011) Molecular insights into the pathogenesis of Alzheimer's disease and its relationship to normal aging. PLoS One 6:e29610

151. Borchelt DR, Thinakaran G, Eckman CB, Lee MK, Davenport F, Ratovitsky T, Prada CM, Kim G, Seekins S, Yager D, Slunt HH, Wang R, Seeger M, Levey Al, Gandy SE, Copeland NG, Jenkins NA, Price DL, Younkin SG, Sisodia SS (1996) Familial Alzheimer's disease-linked presenilin 1 variants elevate Abeta1-42/140 ratio in vitro and in vivo. Neuron 17:1005-1013

152. Citron M, Westaway D, Xia W, Carlson G, Diehl T, Levesque G, Johnson-Wood K, Lee M, Seubert P, Davis A, Kholodenko D, Motter R, Sherrington R, Perry B, Yao H, Strome R, Lieberburg I, Rommens J, Kim S, Schenk D, Fraser P, St George Hyslop P, Selkoe DJ (1997) Mutant presenilins of Alzheimer's disease increase production of 42-residue amyloid beta-protein in both transfected cells and transgenic mice. Nat Med 3:67-72

153. Scheuner D, Eckman C, Jensen M, Song X, Citron M, Suzuki N, Bird TD, Hardy J, Hutton M, Kukull W, Larson E, Levy-Lahad E, Viitanen M, Peskind E, Poorkaj P, Schellenberg G, Tanzi R, Wasco W, Lannfelt L, Selkoe D, Younkin S (1996) Secreted amyloid beta-protein similar to that in the senile plaques of Alzheimer's disease is increased in vivo by the presenilin 1 and 2 and APP mutations linked to familial Alzheimer's disease. Nat Med 2:864-870

154. Shioi J, Georgakopoulos A, Mehta P, Kouchi Z, Litterst CM, Baki L, Robakis NK (2007) FAD mutants unable to increase neurotoxic Abeta 42 suggest that mutation effects on neurodegeneration may be independent of effects on Abeta. J Neurochem 101:674-681

155. Gomez-Isla T, Growdon WB, McNamara MJ, Nochlin D, Bird TD, Arango JC, Lopera F, Kosik KS, Lantos PL, Cairns NJ, Hyman BT (1999) The impact of different presenilin 1 andpresenilin 2 mutations on amyloid deposition, neurofibrillary changes and neuronal loss in the familial Alzheimer's disease 
brain: evidence for other phenotype-modifying factors. Brain 122(Pt 9):1709-1719

156. Bentahir M, Nyabi O, Verhamme J, Tolia A, Horré K, Wiltfang J, Esselmann H, DeStrooper B (2006) Presenilin clinical mutations can affect $\gamma$-secretase activity by different mechanisms. J Neurochem 96:732-742

157. Murayama O, Murayama M, Honda T, Sun X, Nihonmatsu N, Takashima A (1999) Twenty-nine missense mutations linked with familial Alzheimer's disease alter the processing of presenilin 1. Prog Neuro-Psychopharmacol Biol Psychiatry 23:905-913

158. Walker ES, Martinez M, Brunkan AL, Goate A (2005) Presenilin 2 familial Alzheimer's disease mutations result in partial loss of function and dramatic changes in A 42/40 ratios. J Neurochem 92:294-301

159. Potter $H$ (1992) The involvement of astrocytes and an acute phase response in the amyloid deposition of Alzheimer's disease. Prog Brain Res 94:447-458

160. Saito T, Suemoto T, Brouwers N, Sleegers K, Funamoto S, Mihira N, Matsuba Y, Yamada K, Nilsson P, Takano J, Nishimura M, Iwata N, Van Broeckhoven C, Ihara Y, Saido TC (2011) Potent amyloidogenicity and pathogenicity of Abeta43. Nat Neurosci 14:1023-1032

161. Benilova I, De Strooper B (2011) An overlooked neurotoxic species in Alzheimer's disease. Nat Neurosci 14:949-950

162. Bernardi L, Tomaino C, Anfossi M, Gallo M, Geracitano S, Costanzo A, Colao R, Puccio G, Frangipane F, Curcio SAM, Mirabelli M, Smirne N, lapaolo D, Maletta RG, Bruni AC (2009) Novel PSEN1 and PGRN mutations in early-onset familial frontotemporal dementia. Neurobiol Aging 30:1825-1833

163. Ishikawa A, Piao YS, Miyashita A, Kuwano R, Onodera O, Ohtake H, Suzuki M, Nishizawa M, Takahashi H (2005) A mutant PSEN1 causes dementia with Lewy bodies and variant Alzheimer's disease. Ann Neurol 57:429-434

164. Sitek EJ, Narozanska E, Peplonska B et al (2013) A patient with posterior cortical atrophy possesses a novel mutation in the presenilin 1 gene. PLoS One 8:e61074

165. Binetti G, Signorini S, Squitti R, Alberici A, Benussi L, Cassetta E, Frisoni GB, Barbiero L, Feudatari E, Nicosia F, Testa C, Zanetti O, Gennarelli M, Perani D, Anchisi D, Ghidoni R, Rossini PM (2003) Atypical dementia associated with a novel presenilin-2 mutation. Ann Neurol 54:832-836

166. Boeve BF, Baker M, Dickson DW, Parisi JE, Giannini C, Josephs KA, Hutton M, Pickering-Brown SM, Rademakers R, Tang-Wai D, Jack CR Jr, Kantarci K, Shiung MM, Golde T, Smith GE, Geda YE, Knopman DS, Petersen RC (2006) Frontotemporal dementia and parkinsonism associated with the IVS1 + 1G- > A mutation in progranulin: a clinicopathologic study. Brain 129:3103-3114

167. Pickering-Brown SM, Baker M, Gass J, Theuns J, Rademakers R, Saerens J, Pickut BA, Peeters K, van den Broeck M, Vennekens K, Claes S, Cruts M, Cras P, Martin JJ, Van Broeckhoven C, De Deyn PP (2006) Mutations in progranulin explain atypical phenotypes with variants in MAPT. Brain 129:3124-3126

168. Dermaut B, Kumar-Singh S, Engelborghs S et al (2004) A novel presenilin 1 mutation associated with Pick's disease but not beta-amyloid plaques. Ann Neurol 55:617-626

169. Shen J, Kelleher RJ 3rd (2007) The presenilin hypothesis of Alzheimer's disease: evidence for a loss-of-function pathogenic mechanism. Proc Natl Acad Sci U S A 104:403-409

170. Beglopoulos V, Sun X, Saura CA, Lemere CA, Kim RD, Shen J (2004) Reduced $\beta$-Amyloid Production and Increased Inflammatory Responses in Presenilin Conditional Knock-out Mice. J Biol Chem 279:46907-46914

171. Wang H, Megill A, He K, Kirkwood A, Lee H-K (2012) Consequences of Inhibiting Amyloid Precursor Protein Processing Enzymes on Synaptic Function and Plasticity. Neural Plast 2012:24

172. Castellano JM, Kim J, Stewart FR, Jiang H, DeMattos RB, Patterson BW, Fagan AM, Morris JC, Mawuenyega KG, Cruchaga C, Goate AM, Bales KR, Paul SM, Bateman RJ, Holtzman DM (2011) Human apoE isoforms differentially regulate brain amyloid-beta peptide clearance. Sci Transl Med 3:89ra57

173. Laskowitz DT, Goel S, Bennett ER, Matthew WD (1997) Apolipoprotein E suppresses glial cell secretion of TNF-alpha. J Neuroimmunol 76:70-74

174. Vitek MP, Brown CM, Colton CA (2009) APOE genotype-specific differences in the innate immune response. Neurobiol Aging 30:1350-1360

175. Hoane MR, Kaufman N, Vitek MP, McKenna SE (2009) COG1410 improves cognitive performance and reduces cortical neuronal loss in the traumatically injured brain. J Neurotrauma 26:121-129

176. Tukhovskaya EA, Yukin AY, Khokhlova ON, Murashev AN, Vitek MP (2009) COG1410, a novel apolipoprotein-E mimetic, improves functional and morphological recovery in a rat model of focal brain ischemia. J Neurosci Res 87:677-682

177. Vitek MP, Christensen DJ, Wilcock D, Davis J, Van Nostrand WE, Li FQ, Colton CA (2012) APOE-mimetic peptides reduce behavioral deficits, plaques and tangles in Alzheimer's disease transgenics. Neurodegener Dis 2012 10(1-4):122-126

178. Ghosal K, Vogt DL, Liang M, Shen Y, Lamb BT, Pimplikar SW (2009) Alzheimer's disease-like pathological features in transgenic mice expressing the APP intracellular domain. Proc Natl Acad Sci U S A 106:18367-18372

179. Tamayev R, Matsuda S, Giliberto L, Arancio O, D'Adamio L (2011) APP heterozygosity averts memory deficit in knockin mice expressing the Danish dementia BRI2 mutant. EMBO J 30:2501-2509

180. Kuhn PH, Wang H, Dislich B, Colombo A, Zeitschel U, Ellwart JW, Kremmer E, Rossner S, Lichtenthaler SF (2010) ADAM10 is the physiologically relevant, constitutive alpha-secretase of the amyloid precursor protein in primary neurons. EMBO J 29:3020-3032

181. Epis R, Marcello E, Gardoni F, Vastagh C, Malinverno M, Balducci C, Colombo A, Borroni B, Vara H, Dell'Agli M, Cattabeni F, Giustetto M, Borsello T, Forloni G, Padovani A, Di Luca M (2010) Blocking ADAM10 synaptic trafficking generates a model of sporadic Alzheimer's disease. Brain 133:3323-3335

182. Turner PR, O'Connor K, Tate WP, Abraham WC (2003) Roles of amyloid precursor protein and its fragments in regulating neural activity, plasticity and memory. Prog Neurobiol 70:1-32

183. Craft S (2005) Insulin resistance syndrome and Alzheimer's disease: Age- and obesity-related effects on memory, amyloid, and inflammation. Neurobiol Aging 26:65-69

184. Liu Y, Liu F, Grundke lqbal I, lqbal K, Gong CX (2011) Deficient brain insulin signalling pathway in Alzheimer's disease and diabetes. J Pathol 225:54-62

185. Talbot K, Wang HY, Kazi H, Han LY, Bakshi KP, Stucky A, Fuino RL, Kawaguchi KR, Samoyedny AJ, Wilson RS, Arvanitakis Z, Schneider JA, Wolf BA, Bennett DA, Trojanowski JQ, Arnold SE (2012) Demonstrated brain insulin resistance in Alzheimer's disease patients is associated with IGF-1 resistance, IRS-1 dysregulation, and cognitive decline. J Clin Invest 122:1316-1338

186. de Alvaro C, Teruel T, Hernandez R, Lorenzo M (2004) Tumor Necrosis Factor a Produces Insulin Resistance in Skeletal Muscle by Activation of Inhibitor KB Kinase in a p38 MAPK-dependent Manner. J Biol Chem 279:17070-17078

187. Clark I, Atwood C, Bowen R, Paz-Filho G, Vissel B (2012) Tumor necrosis factor-induced cerebral insulin resistance in Alzheimer's disease links numerous treatment rationales. Pharmacol Rev 64:1004-1026

188. Tweedie D, Ferguson RA, Fishman K, Frankola KA, Van Praag H, Holloway HW, Luo W, Li Y, Caracciolo L, Russo I, Barlati S, Ray B, Lahiri DK, Bosetti F Greig NH, Rosi S (2012) Tumor necrosis factor-alpha synthesis inhibitor 3,6'-dithiothalidomide attenuates markers of inflammation, Alzheimer pathology and behavioral deficits in animal models of neuroinflammation and Alzheimer's disease. J Neuroinflammation 9:106

189. McClean PL, Holscher C (2014) Liraglutide can reverse memory impairment, synaptic loss and reduce plaque load in aged APP/PS1 mice, a model of Alzheimer's disease. Neuropharmacology 76:57-67

190. Bomfim TR, Forny-Germano L, Sathler LB, Brito-Moreira J, Houzel JC, Decker H, Silverman MA, Kazi H, Melo HM, McClean PL, Holscher C, Arnold SE, Talbot K, Klein WL, Munoz DP, Ferreira ST, De Felice FG (2012) An anti-diabetes agent protects the mouse brain from defective insulin signaling caused by Alzheimer's disease- associated Abeta oligomers. J Clin Invest 122:1339-1353

191. Akiyama H, Barger S, Barnum S, Bradt B, Bauer J, Cole GM, Cooper NR, Eikelenboom P, Emmerling M, Fiebich BL, Finch CE, Frautschy S, Griffin WS, Hampel H, Hull M, Landreth G, Lue L, Mrak R, Mackenzie IR, McGeer PL, O'Banion MK, Pachter J, Pasinetti G, Plata-Salaman C, Rogers J, Rydel R, Shen Y, Streit W, Strohmeyer R, Tooyoma I (2000) Inflammation and Alzheimer's disease. Neurobiol Aging 21:383-421

192. Goldgaber D, Harris HW, Hla T, Maciag T, Donnelly RJ, Jacobsen JS, Vitek MP, Gajdusek DC (1989) Interleukin 1 regulates synthesis of amyloid betaprotein precursor mRNA in human endothelial cells. Proc Natl Acad Sci U S A 86:7606-7610

193. Lourenco MV, Clarke JR, Frozza RL, Bomfim TR, Forny-Germano L, Batista AF, Sathler LB, Brito-Moreira J, Amaral OB, Silva CA, Freitas-Correa L, EspiritoSanto S, Campello-Costa P, Houzel JC, Klein WL, Holscher C, Carvalheira JB, Silva AM, Velloso LA, Munoz DP, Ferreira ST, De Felice FG (2013) TNF-alpha mediates PKR-dependent memory impairment and brain IRS-1 inhibition induced by Alzheimer's beta-amyloid oligomers in mice and monkeys. Cell Metab 18:831-843 
194. Russo I, Caracciolo L, Tweedie D, Choi SH, Greig NH, Barlati S, Bosetti F (2012) 3,6'-Dithiothalidomide, a new TNF-alpha synthesis inhibitor, attenuates the effect of Abeta1-42 intracerebroventricular injection on hippocampal neurogenesis and memory deficit. J Neurochem 122:1181-1192

195. Rao JS, Kellom M, Kim HW, Rapoport SI, Reese EA (2012) Neuroinflammation and synaptic loss. Neurochem Res 37:903-910

196. Detrait ER, Danis B, Lamberty Y, Foerch P (2014) Peripheral administration of an anti-TNF-alpha receptor fusion protein counteracts the amyloid induced elevation of hippocampal TNF-alpha levels and memory deficits in mice. Neurochem Int 72C:10-13

197. Goedert M (2004) Tau protein and neurodegeneration. Semin Cell Dev Biol 15:45-49

198. Vishnu VY (2013) Can tauopathy shake the amyloid cascade hypothesis? Nat Rev Neurol 9:356-356

199. Arendt T, Stieler J, Strijkstra AM, Hut RA, Rudiger J, Van der Zee EA, Harkany T, Holzer M, Hartig W (2003) Reversible paired helical filament-like phosphorylation of tau is an adaptive process associated with neuronal plasticity in hibernating animals. J Neurosci 23:6972-6981

200. Kettenmann H, Kirchhoff F, Verkhratsky A (2013) Microglia: New Roles for the Synaptic Stripper. Neuron 77:10-18

201. Chung W-S, Clarke LE, Wang GX, Lee SH, Kim JS, Jung YS Hwang SH, Ha NC, Seol WG, Lee J, Park BJ (2013) Astrocytes mediate synapse elimination through MEGF10 and MERTK pathways. Nature 504:394-400

202. Tremblay ME, Lowery RL, Majewska AK (2010) Microglial interactions with synapses are modulated by visual experience. PLoS Biol 8:e1000527

203. Diniz LP, Almeida JC, Tortelli V, Vargas Lopes C, Setti-Perdigao P, Stipursky J, Kahn SA, Romao LF, de Miranda J, Alves-Leon SV, de Souza JM, Castro NG, Panizzutti R, Gomes FCA (2012) Astrocyte-induced synaptogenesis is mediated by transforming growth factor beta signaling through modulation of D-serine levels in cerebral cortex neurons. J Biol Chem 287:41432-41445

204. Parkhurst CN, Yang G, Ninan I, Savas JN, Yates IJR, Lafaille JJ, Hempstead BL, Littman DR, Gan W-B (2013) Microglia Promote Learning-Dependent Synapse Formation through Brain-Derived Neurotrophic Factor. Cell 155:1596-1609

205. Perea G, Navarrete M, Araque A (2009) Tripartite synapses: astrocytes process and control synaptic information. Trends Neurosci 32:421-431

206. Wake H, Moorhouse AJ, Jinno S, Kohsaka S, Nabekura J (2009) Resting Microglia Directly Monitor the Functional State of Synapses In Vivo and Determine the Fate of Ischemic Terminals. J Neurosci 29:3974-3980

207. Strobel G Early-onset familial AD Prevention—Do eFAD Families Hold the Key? http://www.alzforum.org/early-onset-familial-ad/research/preventiondo-efad-families-hold-key. Accessed 22.05.2014

208. Button KS, loannidis JPA, Mokrysz C, Nosek BA, Flint J, Robinson ESJ, Munafo MR (2013) Power failure: why small sample size undermines the reliability of neuroscience. Nat Rev Neurosci 14:365-376

209. Tsilidis KK, Panagiotou OA, Sena ES, Aretouli E, Evangelou E, Howells DW, Al-Shahi SR, Macleod MR, loannidis JP (2013) Evaluation of excess significance bias in animal studies of neurological diseases. PLoS Biol 11:e1001609

210. Crusio WE, Goldowitz D, Holmes A, Wolfer D (2009) Standards for the publication of mouse mutant studies. Genes Brain Behav 8:1-4

211. Richter SH, Garner JP, Wurbel H (2009) Environmental standardization: cure or cause of poor reproducibility in animal experiments? Nat Methods 6:257-261

doi:10.1186/s40478-014-0135-5

Cite this article as: Morris et al:: Inconsistencies and Controversies Surrounding the Amyloid Hypothesis of Alzheimer's Disease. Acta Neuropathologica Communications 2014 2:135

\section{Submit your next manuscript to BioMed Central and take full advantage of:}

- Convenient online submission

- Thorough peer review

- No space constraints or color figure charges

- Immediate publication on acceptance

- Inclusion in PubMed, CAS, Scopus and Google Scholar

- Research which is freely available for redistribution 